described in ref 5 . The workup included chromatography $(3 \times$ $30, \mathrm{CH}_{2} \mathrm{Cl}_{2}$ ) and yielded $1.87 \mathrm{~g}(82 \%)$ of $2 \mathrm{a}: \mathrm{mp} 59-62{ }^{\circ} \mathrm{C}$ (lit. ${ }^{27}$ $\left.\mathrm{mp} 65-66^{\circ} \mathrm{C}\right)$.

N-(2-Chloroethyl)toluene-4-sulfonamide (3a). Authentic probe: $1 \mathrm{a}$ was added to a mixture of $\mathrm{AlCl}_{3}$ and $\mathrm{CH}_{2} \mathrm{Cl}_{2}$. After $10 \mathrm{~min}$ the mixture was washed with water. Evaporation of the organic layer provided 3a: $\operatorname{mp~} 98^{\circ} \mathrm{C}$ (lit. ${ }^{28} \mathrm{mp} 99^{\circ} \mathrm{C}$ ).

Acknowledgment. We thank the Deutsche Forschungsgemeinschaft and the Fonds der Chemischen In-

(27) Johnson, T. B.; Guest, H. G. Am. Chem. J. 1909, 42, 340-353. (28) Peacock, D. H.; Dutta, U. C. J. Chem. Soc. 1934, 1303-1305. dustrie for financial support and Professor Hans Suschitzky for the help in improving the English.

Registry No. 1a, 3634-89-7; 2b, 5450-75-9; 3a, 6331-00-6; 4b, 19871-46-6; 5b, 117583-57-0; 6, 1520-42-9; 7a, 70-55-3; 7b, 98-10-2; 7c, 88-05-1; cis-8b, 110143-77-6; trans-8b, 110143-78-7; 9b, $117583-58-1$; 10, 632-50-8; 11a, 5048-64-6; 11b, 5048-63-5; 11c, $117583-63-8 ; 12 \mathbf{a A}, 117583-64-9 ; \mathbf{1 2 a} \mathbf{P}, 117583-61-6 ; 12 \mathbf{a T}$, 117583-69-4; 12bP, 42801-56-9; 12cA, 117583-68-3; 12cP, 117583-59-2; 12cT, 117583-72-9; 13A, 117583-65-0; 13P, 1985-96-2; 13T, 117583-70-7; 14A, 117583-66-1; 14P, 1634-11-3; 14T, 117583-71-8; 15a, 2849-72-1; 15c, 117583-60-5; 16a, 1206-41-3; 16b, 1203-15-2; 17a, 110871-36-8; 18aP, 110871-37-9; 18aT, 117583-67-2; 18bP, 117583-62-7; PH, 71-43-2; AN, 100-66-3; TH, 108-88-3.

\title{
Stereochemical Aspects of the "tert-Amino Effect". 1. Regioselectivity in the Synthesis of Pyrrolo[1,2-a ]quinolines and Benzo[c]quinolizines
}

\author{
Walter H. N. Nijhuis, ${ }^{\dagger}$ Willem Verboom ${ }^{\dagger}$ A. Abu El-Fadl $,{ }^{\ddagger}, \$$ Sybolt Harkema, ${ }^{\ddagger}$ and \\ David N. Reinhoudt*,† \\ Laboratories of Organic Chemistry and Chemical Physics, University of Twente, 7500 AE Enschede, \\ The Netherlands
}

Received June 20, 1988

\begin{abstract}
Substituted 2-vinyl- $N, N$-dialkylanilines cyclize in refluxing 1-butanol to give substituted pyrrolo[1,2-a]quinolines and benzo[c]quinolizines. This reaction proceeds via a 1,5-hydrogen transfer and subsequent $\mathrm{C}-\mathrm{C}$ bond formation. When in the 2-vinyl- $N, N$-dialkylanilines $4, \mathrm{R}^{1}=\mathrm{H}$ and $\mathrm{R}^{2}=\mathrm{H}(\mathbf{4 a}, \mathbf{d}), \mathrm{CH}_{3}(\mathbf{4 b}, \mathbf{e})$, or $\mathrm{C}_{2} \mathrm{H}_{5}(\mathbf{4 f})$, the cyclization products $5 \mathbf{a}, \mathbf{b}, \mathbf{d}-\mathbf{f}$ are formed selectively, with the substituent $R^{2}$ at the bridgehead carbon atom. This regioselectivity is lost when $\mathrm{R}^{2}=\mathrm{CH}_{2} \mathrm{OCH}_{3}(4 \mathrm{c}, \mathrm{g})$, and a mixture of the regioisomers $5 \mathrm{c}, \mathrm{g}, 6 \mathrm{c}, \mathrm{g}$, and $7 \mathrm{c}, \mathrm{g}$ is formed. Reaction of compounds $4 \mathbf{h}-\mathbf{n}\left(\mathrm{R}^{1}=\mathrm{CH}_{3}\right)$ yields the pyrrolo[1,2-a]quinolines $5-7(\mathbf{h}-\mathbf{j})$ and benzo[c]quinolizines $5-7(\mathbf{k}-\mathbf{n})$ selectively, in which the substituent at the bridgehead carbon atom is at the same face of the molecule (cis) as the hydrogen atom at $\mathrm{C}-5[5-7(\mathbf{h}-\mathbf{j})]$ or at $\mathrm{C}-6[5-7(\mathbf{k}-\mathbf{n})]$. The configuration of these compounds was determined by ${ }^{1} \mathrm{H}$ NOE difference spectroscopy and single-crystal X-ray analysis $(6 \mathbf{n})$. Heating of $40-q\left(\mathrm{R}^{1}=4-\mathrm{C}_{6} \mathrm{H}_{4} \mathrm{CH}_{3}\right)$ in refluxing 1-butanol gives mixtures of the cis $[5-7(0-q)]$ and trans $[8-10(0-q)]$ compounds. The mechanism of these cyclizations, which are further examples of the "tert-amino effect", and the effect of variation in substituents are discussed.
\end{abstract}

\section{Introduction}

In 1972 Meth-Cohn and Suschitzky reviewed the formation of heterocycles by ring closure of ortho-substituted tertiary anilines (the "tert-amino effect"). ${ }^{1}$ We have demonstrated that this type of reaction has a wider applicability, e.g. for the synthesis of pyrrolo- and pyrido$[1,2-a]$ indoles, pyrrolo[1,2-a]quinolines, benzo $[c]$ quinolizines, $[1,4]$ oxazino $[4,3-a]$ quinolines, ${ }^{2}$ and pyrazinoquinolines. ${ }^{3}$ The synthesis of benzoxazines, ${ }^{4}$ benzothiazines, and a quinoxaline $e^{5}$ can also be regarded as examples of this type of reaction. The formation of all these compounds takes place via either a 1,5- or a 1,6-hydrogen shift, depending on the structure of the reactant. The two different types of dipolar species subsequently undergo cyclization to give 6 - and 5-membered rings, respectively.

In the course of our investigations of the "tert-amino effect" we have studied the formation of pyrrolo[1,2-a]quinolines and benzo[c]quinolizines in more detail, in particular the regioselective aspects. When we could control the regioselectivity of the cyclization reaction this would greatly enhance the synthetic utility of the "tert-

\footnotetext{
${ }^{\dagger}$ Laboratory of Organic Chemistry.

$\$$ Laboratory of Chemical Physics.

${ }^{3}$ Present address: Physics Department, Faculty of Science, Assiut University, Assiut, Egypt.
}

amino effect" in heterocyclic synthesis.

In the present paper dealing with this regioselectivity we describe the thermal isomerization of 2-vinyl- $N, N$-dialkylanilines $4\left(\mathrm{X}=-, \mathrm{CH}_{2}\right)$ with different substituents at the $\alpha$-carbon atom of the vinyl moiety $\left(\mathrm{R}^{1}=\mathrm{H}, \mathrm{CH}_{3}\right.$, or $4-\mathrm{C}_{6} \mathrm{H}_{4} \mathrm{CH}_{3}$ ) and at one of the two carbon atoms adjacent to nitrogen of the amine moiety $\left(\mathrm{R}^{2}=\mathrm{H}, \mathrm{CH}_{3}\right.$, $\mathrm{CH}_{2} \mathrm{CH}_{3}$, or $\mathrm{CH}_{2} \mathrm{OCH}_{3}$ ). Firstly, we describe the effect of the nature (size, stabilizing effect) of the substituent $\mathrm{R}^{2}$ when $R^{1}=H$. Secondly, the influence of both the substituents $R^{1}(\neq \mathrm{H})$ and $R^{2}$ on the regioselectivity of the cyclization will be discussed.

\section{Results}

Synthesis of the Starting Materials 4. The starting compounds 4 for the thermal isomerization were conven-

(1) Meth-Cohn, O.; Suschitzky, H. Adv. Heterocycl. Chem. 1972, 14, 211.

(2) Verboom, W.; Reinhoudt, D. N.; Visser, R.; Harkema, S. J. Org. Chem. 1984, 49, 269.

(3) Nijhuis, W. H. N.; Verboom, W.; Reinhoudt, D. N. Synthesis 1987, 641.

(4) Verboom, W.; van Dijk, B. G.; Reinhoudt, D. N. Tetrahedron Lett. $1983,24,3923$.

(5) Verboom, W.; Hamzink, M. R. J.; Reinhoudt, D. N.; Visser, R. Tetrahedron Lett. 1984, 25, 4309. 
<smiles>[R]C(=O)c1ccccc1F</smiles>

$$
\begin{aligned}
& \text { a } \mathrm{R}^{1}=\mathrm{H} \\
& \text { b } \mathrm{R}^{1}=\mathrm{CH}_{3} \\
& \text { c } \mathrm{R}^{1}=4 \cdot \mathrm{C}_{6} \mathrm{H}_{4} \mathrm{CH}_{3}
\end{aligned}
$$

Chart I<smiles>[R]C1C[Y]CCN1</smiles>

2

$$
\begin{array}{ll}
\text { a } X=-; \mathrm{R}^{2}=\mathrm{H} & \text { d } \mathrm{X}=\mathrm{CH}_{2} ; \mathrm{R}^{2}=\mathrm{H} \\
\text { b } \mathrm{X}=-; \mathrm{R}^{2}=\mathrm{CH}_{3} & \text { e } \mathrm{X}=\mathrm{CH}_{2} ; \mathrm{R}^{2}=\mathrm{CH}_{3} \\
\text { c } \mathrm{X}=-; \mathrm{R}^{2}=\mathrm{CH}_{2} \mathrm{OCH} \mathrm{CH}_{3} & \text { f } \mathrm{X}=\mathrm{CH}_{2} ; \mathrm{R}^{2}=\mathrm{CH}_{2} \mathrm{CH}_{3} \\
& \text { g } \mathrm{X}=\mathrm{CH}_{2} ; \mathrm{R}^{2}=\mathrm{CH}_{2} \mathrm{OCH}_{3}
\end{array}
$$<smiles>[R]C(=O)c1ccccc1N1CCC[X]C1[R]</smiles><smiles>[R]/C(C#N)=C(/C#N)c1ccccc1N1CC[X]C[C@H]1[R]</smiles><smiles>[Y]C[C@]12C[Y]CCN1c1ccccc1[C@@H]([2H])C2(C)C</smiles>

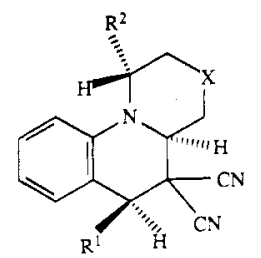<smiles>[R][C@H]1c2ccccc2N2[C@H]([Z])C[Y]C[C@]2([2H])C1(C#N)C#N</smiles>

5

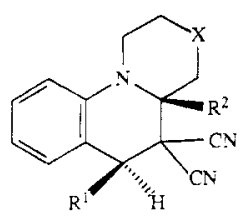

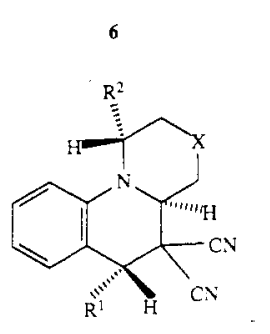

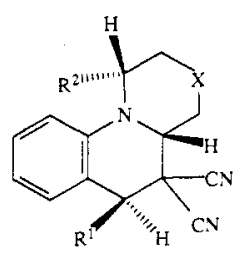
8

$\mathrm{R}^{i}=\mathrm{H}$

a $X=-, R^{2}=H$

b $\mathrm{X}=-\mathrm{R}^{2}=\mathrm{CH}_{3}$

c $\mathrm{X}=-\mathrm{R}^{2}=\mathrm{CH}_{2} \mathrm{OCH}_{3}$

d $\mathrm{X}=\mathrm{CH}_{2}, \mathrm{R}^{2}=\mathrm{H}$

e $\mathrm{X}=\mathrm{CH}_{2}, \mathrm{R}^{2}=\mathrm{CH}_{3}$

r $\mathrm{X}=\mathrm{CH}_{2}, \mathrm{R}^{2}=\mathrm{CH}_{2} \mathrm{CH}_{3}$

If $\mathrm{X}=\mathrm{CH}_{2}, \mathrm{R}^{2}=\mathrm{CH}_{2} \mathrm{OCH}_{3}$

$$
\begin{aligned}
\mathrm{R}^{1} & =\mathrm{CH}_{3} \\
\text { h } \mathrm{X} & =-\cdot \mathrm{R}^{2}=\mathrm{H} \\
\text { i } \mathrm{X} & =-\cdot \mathrm{R}^{2}=\mathrm{CH}_{3} \\
\text { j } \mathrm{X} & =-\mathrm{R}^{2}=\mathrm{CH}_{2} \mathrm{OCH}_{3} \\
\text { k } \mathrm{X} & =\mathrm{CH}_{2}, \mathrm{R}^{2}=\mathrm{H} \\
\text { I } \mathrm{X} & =\mathrm{CH}_{2}, \mathrm{R}^{2}=\mathrm{CH}_{3} \\
\text { m } \mathrm{X} & =\mathrm{CH}_{2}, \mathrm{R}^{2}=\mathrm{CH}_{2} \mathrm{CH}_{3} \\
\text { n } \mathrm{X} & =\mathrm{CH}_{2}, \mathrm{R}^{2}=\mathrm{CH}_{2} \mathrm{OCH}_{3}
\end{aligned}
$$

iently prepared from 2-fluorobenzaldehyde (1a), 2fluoroacetophenone (1b), and 2-fluoro-4'-methylbenzophenone (1c). The latter compound was synthesized from 2 -fluorobenzaldehyde via a Grignard reaction with (4methylphenyl)magnesium bromide and subsequent oxidation of the resulting secondary alcohol with pyridinium chlorochromate $(\mathrm{PCC})$ in dichloromethane. ${ }^{6}$

The first step in the synthesis of compounds 4 involves a nucleophilic substitution of the fluorine atom in these compounds by a pyrrolidine $(2 \mathrm{a}-\mathbf{c})$ or a piperidine group $(2 \mathrm{~d}-\mathrm{g})$ in refluxing $\mathrm{N}, \mathrm{N}$-dimethylformamide (DMF) in the presence of $\mathrm{K}_{2} \mathrm{CO}_{3}{ }^{7}$ These reactions afford the substituted benzaldehydes $3 \mathbf{a}-\mathbf{g}$, acetophenones $3 \mathbf{h}-\mathbf{n}$, and benzophenones 3o-q, respectively (Chart I). The second

(6) Corey, E. J.; Suggs, J. W. Tetrahedron Lett. 1975, 2647.

(7) Niewiadomski, K. B.; Suschitzky, H. J. Chem. Soc., Perkin Trans. $11975,1679$.
Table I. Yields and Reaction Times of the Products Obtained by Thermal Isomerization of the Condensation Compounds 4a-q

\begin{tabular}{ccccc}
\hline & reaction & \multicolumn{3}{c}{ yield, \% } \\
\cline { 3 - 5 } starting compd 4 & time & $\mathbf{5}$ & $\mathbf{6}$ & $\mathbf{7}$ \\
\hline $\mathbf{a}$ & $2 \mathrm{~h}$ & 82 & & \\
$\mathbf{b}$ & $2 \mathrm{~h}$ & 85 & & 17 \\
$\mathbf{c}$ & $1.5 \mathrm{~h}$ & 46 & 19 & \\
$\mathbf{d}$ & $2 \mathrm{~h}$ & 78 & & \\
$\mathbf{e}$ & $1.5 \mathrm{~h}$ & $79^{a}$ & & \\
$\mathbf{f}$ & $\mathbf{1 . 5 \mathrm { h }}$ & $80^{a}$ & & \\
$\mathbf{g}$ & $2.5 \mathrm{~h}$ & 71 & 12.5 & 12.5 \\
$\mathbf{h}$ & $5 \mathrm{~h}$ & 79 & & \\
$\mathbf{i}$ & $5 \mathrm{~h}$ & 79 & & \\
$\mathbf{j}$ & $5 \mathrm{~h}$ & 33 & 35 & 6 \\
$\mathbf{k}$ & $2 \mathrm{~h}$ & 88 & & \\
$\mathbf{l}$ & $2 \mathrm{~h}$ & 88 & & \\
$\mathbf{m}$ & $2.5 \mathrm{~h}$ & 86 & & \\
$\mathbf{n}$ & $3 \mathrm{~h}$ & 56 & 28 & 8 \\
$\mathbf{0}$ & $3 \mathrm{~d}$ days & $86^{b}$ & & \\
$\mathbf{p}$ & 3 days & $76^{b}$ & $13^{b}$ & $9^{b}$ \\
$\mathbf{q}$ & 3 days & $16^{b}$ & $41^{b}$ & $15^{b}$
\end{tabular}

${ }^{a}$ Overall yield, starting from $3 e$ and $3 f$, respectively. ${ }^{b}$ Total yields for the formed cis (5-7) and trans isomers (8-10) starting from $30-q$.

step comprises a Knoevenagel condensation of the carbonyl group of 3 with malononitrile in toluene at room temperature to give $4 \mathrm{a}-\mathrm{g}$ and $4 \mathrm{~h}-\mathrm{n}$ in high yields (Chart I). In the case of 2-(2-methyl- and 2-ethyl-1-piperidinyl)benzaldehyde (3e and 3f) the malononitrile adduct could not be obtained pure because mixtures of the condensation product (4e or $\mathbf{4 f}$ ) and the product of ring closure (5e or 5f) were isolated.

The condensation of the benzophenone derivatives $(30-q)$ did not take place under these conditions. However, by elevating the reaction temperature, the condensation of 3o-q to 4o-q could be accomplished. Since at the higher reaction temperatures ring closure proceeds (much) faster than condensation, hardly any condensation product was present in these reaction mixtures, and therefore no attempt was made to isolate compounds $40-q^{8,12}$

Thermal Isomerization of 2-Vinyl- $N, N$-dialkylanilines $4 a-q$. The objective of our work was to study the regioselectivity of the cyclization of 2-vinyl- $N, N$-dialkylanilines $(\mathbf{4} \mathbf{a}-\mathbf{q})$. Firstly, we will describe the effect on the regioselectivity by variation of $R^{2}$ (when $R^{1}=H$ ) and the $N, N$-dialkylamino group is a pyrrolidinyl $(\mathrm{X}=-)$ or a piperidinyl $\left(\mathrm{X}=\mathrm{CH}_{2}\right)$ moiety. Secondly, the effect of various $R^{2}$ groups will be described when $\mathrm{R}^{1}=\mathrm{CH}_{3}$ (X $=-, \mathrm{CH}_{2}$ ). Thirdly, the effect of $\mathrm{R}^{2}$ on the regioselectivity when $\mathrm{R}^{1}=4-\mathrm{C}_{6} \mathrm{H}_{4} \mathrm{CH}_{3}(\mathrm{X}=-)$ will be described.

Cyclization of $4 \mathrm{a}-\mathrm{g}\left(\mathrm{R}^{1}=\mathrm{H}\right)$. Compound $4 \mathrm{a}$ was reacted in refluxing 1-butanol to give 1,2,3,3a-tetrahydropyrrolo[1,2-a]quinoline-4,4(5H)-dicarbonitrile (5a) in a yield of $82 \%$ (Table I). ${ }^{2}$ Heating of $4 \mathrm{~b}$ in refluxing 1-butanol afforded selectively $\mathbf{5 b}$ with the substituent $R^{2}$

(8) Unfortunately, we could not isolate the compounds $40-q$, though several attempts have been made. A Knoevenagel condensation with $\mathrm{TiCl}_{4}$ and base did not give the desired compounds; ${ }^{9}$ \& Peterson olefination reaction ${ }^{10}$ and variations thereof and a simple Wittig reaction ${ }^{11}$ to obtain the olefins without the cyano groups did not succeed.

(9) Lehnert, W. Tetrahedron 1973, 29, 635.

(10) Peterson, D. J. J. Org. Chem. 1968, 33, 780.

(11) Wittig, G.; Schölkopf, U. Chem. Ber. 1954, 87, 1318

(12) The condensation reaction and subsequent cyclization, here in most cases described as a two step process, can also be performed in a one-pot procedure. This is demonstrated by the reaction of 3o-q with malononitrile in refluxing 1 -butanol. Heating of the aldehyde $(3 \mathrm{a}-\mathrm{g})$ and acetophenone derivatives $\mathbf{3 h}-\mathbf{n}$ with malononitrile in either refluxing toluene or refluxing 1-butanol gives the cyclized products $5-7(a-n)$ in comparable yields. 
$\left(=\mathrm{CH}_{3}\right)$ at the bridgehead carbon atom in $85 \%$ yield. This was concluded from the ${ }^{1} \mathrm{H}$ and ${ }^{13} \mathrm{C}$ NMR spectral data $\left[{ }^{1} \mathrm{H}\right.$ NMR $\left.\delta 1.26\left(\mathrm{~s}, \mathrm{CH}_{3}\right) ;{ }^{13} \mathrm{C} \mathrm{NMR} \delta 63.8\left[\mathrm{~s}, \mathrm{NC}\left(\mathrm{CH}_{3}\right)\right]\right]$.

However, this regioselectivity was lost in the reaction of $4 \mathrm{c}\left(\mathrm{R}^{2}=\mathrm{CH}_{2} \mathrm{OCH}_{3}\right)$. In this case we obtained a mixture of one diastereomer with the methoxymethyl substituent at C-3a (bridgehead carbon atom) (5c, 46\%) and two diastereomers with a hydrogen atom at C-3a, that could be separated by column chromatography. Each of these two compounds exhibits very characteristic and different signals for the methylene protons of the $\mathrm{CH}_{2} \mathrm{OCH}_{3}$ group in the $200-\mathrm{MHz}^{1} \mathrm{H}$ NMR spectrum (see the Experimental Section). On the basis of the ${ }^{1} \mathrm{H}$ NMR data, compared with those of $6 \mathbf{j}$ and $7 \mathbf{j}$ (vide infra), we concluded that these are $6 \mathbf{c}(19 \%)$ and $7 \mathbf{c}(17 \%)$.

Ring closure of the piperidinyl analogue $4 d\left(R^{1}=R^{2}=\right.$ $\mathrm{H})$ resulted in the formation of 2,3,4,4a-tetrahydro- $1 \mathrm{H}$ benzo[c]quinolizine-5,5(6H)-dicarbonitrile $(5 \mathrm{~d})$ in a yield of $78 \%{ }^{2}$ Heating of crude (vide supra) $4 \mathrm{e}\left(\mathrm{R}^{1}=\mathrm{H}, \mathrm{R}^{2}=\right.$ $\left.\mathrm{CH}_{3}\right)$ and of $4 \mathrm{f}\left(\mathrm{R}^{1}=\mathrm{H}, \mathrm{R}^{2}=\mathrm{CH}_{2} \mathrm{CH}_{3}\right)$ in refluxing 1 butanol gave selectively $5 \mathbf{e}$ and $\mathbf{5 f}$ in overall yields of $79 \%$ and $80 \%$ (based on $3 \mathbf{e}$ and $3 \mathbf{f}$ ), respectively. In these reactions the same regioselectivity is observed as in the ring closure of the pyrrolidinyl analogue $\mathbf{4 b}$.

However, this regioselectivity was again lost when a methoxymethyl substituent is present. Reaction of $4 \mathrm{~g}\left(\mathrm{R}^{1}\right.$ $=\mathrm{H}, \mathrm{R}^{2}=\mathrm{CH}_{2} \mathrm{OCH}_{3}$ ) in refluxing 1-butanol resulted in the formation of one diastereomer with the methoxymethyl group at the bridgehead carbon atom (C-4a) $(5 \mathrm{~g}, 71 \%)$, and a mixture of two diastereomers with a hydrogen atom at $\mathrm{C}-4 \mathrm{a}(6 \mathrm{~g}$ and $7 \mathrm{~g}$, total yield $25 \%$ ). Compound $\mathbf{5 g}$ could be separated from these two compounds by column chromatography. Compounds $6 \mathrm{~g}$ and $\mathbf{7 g}$ could not be separated in this way, but $200-\mathrm{MHz}{ }^{1} \mathrm{H}$ NMR spectroscopy revealed the 1:1 ratio of these two diastereomers. The two isomers exhibit different multiplets at $\delta 4.35-4.2$ and 3.95-3.8 for the $\mathrm{NCH}\left(\mathrm{CH}_{2} \mathrm{OCH}_{3}\right)$ proton. However, upon fractional crystallization one isomer could be obtained pure. ${ }^{13}$ The methylene protons of the $\mathrm{CH}_{2} \mathrm{OCH}_{3}$ group of this isomer exhibit the same characteristic absorptions as those of $\mathbf{6 n}$ (vide infra). Therefore, we could assign the structure $6 \mathrm{~g}$ to this compound.

Cyclization of $4 \mathbf{h}-\mathbf{n}\left(\mathbf{R}^{1}=\mathbf{C H}_{3}\right)$. Subsequently, we studied the reactions of the compounds $4 \mathbf{h}-\mathbf{j}(\mathrm{X}=-)$ and $4 \mathbf{k}-\mathbf{n}\left(\mathrm{X}=\mathrm{CH}_{2}\right)$ in which the $\alpha$-carbon atom of the vinyl moiety is a prochiral center. When the pyrrolidinyl derivative $4 \mathrm{~h}$ was heated in refluxing 1-butanol, exclusively 5h was obtained in $79 \%$ yield. The piperidinyl analogue 4k gave also selectively $\mathbf{5 k}(88 \%)$.

The compounds $\mathbf{5 i}\left(\mathrm{X}=-; \mathrm{R}^{2}=\mathrm{CH}_{3}\right), \mathbf{5 l}\left(\mathrm{X}=\mathrm{CH}_{2} ; \mathrm{R}^{2}\right.$ $\left.=\mathrm{CH}_{3}\right)$, and $5 \mathrm{~m}\left(\mathrm{X}=\mathrm{CH}_{2} ; \mathrm{R}^{2}=\mathrm{CH}_{2} \mathrm{CH}_{3}\right)$ were formed regioselectively by cyclization of $4 \mathbf{i}, 41$, and $4 \mathrm{~m}$ in yields of $79 \%, 88 \%$, and $86 \%$, respectively. Three compounds, $\mathbf{5 j}(33 \%), 6 \mathbf{j}(35 \%)$, and $7 \mathbf{j}(6 \%)$, were isolated upon ring closure of $4 \mathbf{j}\left(\mathrm{X}=-; \mathrm{R}^{2}=\mathrm{CH}_{2} \mathrm{OCH}_{3}\right)$. Cyclization of $4 \mathbf{n}$ $\left(\mathrm{X}=\mathrm{CH}_{2} ; \mathrm{R}^{2}=\mathrm{CH}_{2} \mathrm{OCH}_{3}\right.$ ) gave one isomer with the methoxymethyl substituent at the bridgehead carbon atom $(\mathbf{5 n}, 56 \%)$ and a mixture of two diastereomers, $\mathbf{6 n}$ and $7 \mathbf{n}$, with a hydrogen atom at the bridgehead carbon atom in a combined yield of $36 \%$. These two diastereomers are formed in a ratio of 7:2, as was determined by ${ }^{1} \mathrm{H}$ NMR spectroscopy. The $\mathrm{NCH}\left(\mathrm{CH}_{2} \mathrm{OCH}_{3}\right)$ proton of the major

(13) Unfortunately, we were not able to determine the relative configuration of this isomer by means of ${ }^{1} \mathrm{H}$ NOE difference spectroscopy: irradiation of the bridgehead hydrogen atom $(\mathrm{H}-4 \mathrm{a})$ gave no measurable effect on $\mathrm{H}-1$ and irradiation of $\mathrm{H}-1$ gave no effect on $\mathrm{H}-4 \mathrm{a}$. Attempts to measure the effect of irradiation of $\mathrm{H}-4 \mathrm{a}$ at the methylene hydrogen atoms of the $\mathrm{CH}_{2} \mathrm{OCH}_{3}$ group and reverse were doomed to fail, because the absorptions of these protons in the ${ }^{1} \mathrm{H}$ NMR spectrum coincide.
Chart II

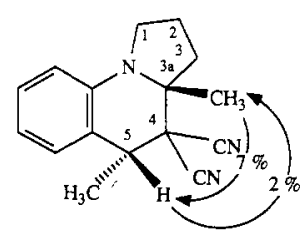

$5 \mathbf{j}$

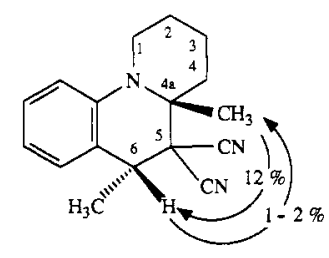

5]

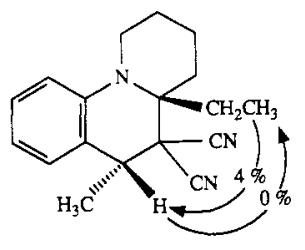

$5 \mathrm{~m}$

Chart III

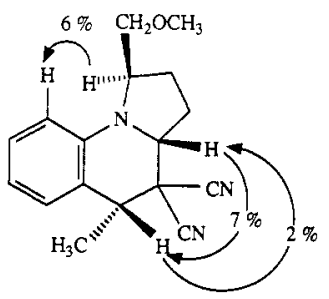

6j

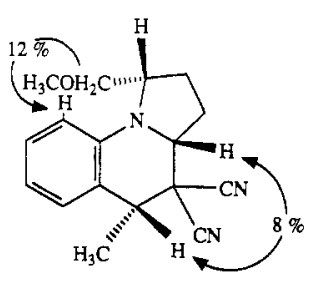

$7 \mathbf{j}$ isomer (6n) exhibits a multiplet at $\delta 4.4-4.25$, and of the minor isomer $(\mathbf{7 n})$ a multiplet at $\delta 3.95-3.8$.

The structures of $5 \mathbf{i}\left(\mathrm{X}=-, \mathrm{R}^{2}=\mathrm{CH}_{3}\right)$ and $\mathbf{5 l}\left(\mathrm{X}=\mathrm{CH}_{2}\right.$, $\mathrm{R}^{2}=\mathrm{CH}_{3}$ ) were determined by ${ }^{1} \mathrm{H}$ NOE difference spectroscopy. This indicated that in both compounds the methyl group at the bridgehead carbon atom and the hydrogen at the benzylic position are at the same face of the molecule. Irradiation of the bridgehead methyl group $\left(\mathrm{CH}_{3}-3 \mathrm{a}\right)$ of $5 \mathrm{i}$ gave a NOE of $7 \%$ at $\mathrm{H}-5$. In reverse, on irradiation of $\mathrm{H}-5$ only a slight enhancement of $2 \%$ was noticed at $\mathrm{CH}_{3}-3 \mathrm{a}$. This difference arises because the protons of $\mathrm{CH}_{3}-3 \mathrm{a}$ have additional and different protons contributing to their relaxation. ${ }^{14}$ The same difference was noticed by irradiating $\mathrm{H}-6$ and $\mathrm{CH}_{3}-4 \mathrm{a}$ of compound 51 (Chart II).

${ }^{1} \mathrm{H}$ NOE difference spectroscopy experiments with $\mathbf{5 m}$ $\left(\mathrm{X}=\mathrm{CH}_{2} ; \mathrm{R}^{2}=\mathrm{C}_{2} \mathrm{H}_{5}\right.$ ) gave almost identical information about the relative positions of the ethyl group and the hydrogen atom at C-6. Irradiation of the methyl group of the $\mathrm{CH}_{2} \mathrm{CH}_{3}$ moiety gave a NOE of $4 \%$ at $\mathrm{H}-6$ but upon irradiation of H-6 no NOE was measured at the ethyl group (Chart II). ${ }^{1} \mathrm{H}$ NOE difference spectroscopy of $\mathbf{5 k}$ gave no reliable results about the position of the hydrogen atoms at C-4a and C-6. However, on the basis of the results obtained by ${ }^{1} \mathrm{H}$ NOE experiments with $\mathbf{5 i}, \mathbf{5 l}$, and $\mathbf{5 m}$, we assume that the relative configuration of $\mathbf{5 k}$ is as depicted (Chart $\mathrm{I}$ ). The relative configuration of the hydrogen atoms at C-3a and C-5 of compound $5 \mathbf{h}$ could not be assigned in this way because the absorptions of the $\mathrm{NCH}_{2}$ hydrogen atoms (H-1) and $\mathrm{H}-5$ coincide. Irradiation of $\mathrm{H}-3 \mathrm{a}$ gave a NOE at $\mathrm{H}-5$ and $\mathrm{H}-1(\approx 3 \%)$. In reverse, irradiation of $\mathrm{H}-5$ and $\mathrm{H}-1$ gave an enhancement at $\mathrm{H}-3 \mathrm{a}$ $(\approx 5 \%)$. Since we have never noticed any effect at $\mathrm{H}-1$ by

(14) Similar observations have been reported, e.g.: Bell, R. A.; Saun ders, J. K. Can. J. Chem. 1970, 48, 4114. Bachers, G. E.; Schaefer, T. Chem. Rev. 1971, 71, 617. Noggle, J. H.; Schirmer, R. E. The Nuclear Overhauser Effect; Academic Press: New York, 1971; p 182 and references cited therein. 


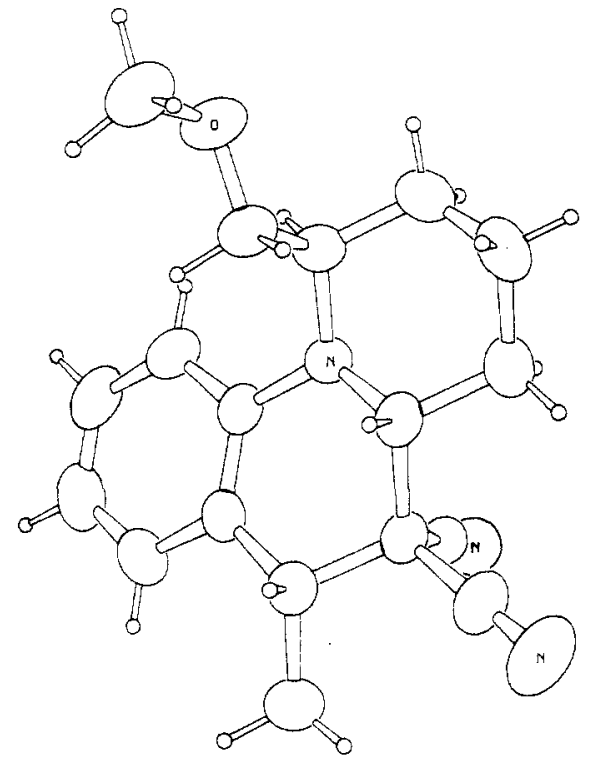

Figure 1. X-ray crystal structure of $6 \mathbf{n}$.

irradiation of $\mathrm{H}-3 \mathrm{a}$ or vice versa (see, e.g. NOE at $6 \mathbf{j}$ and $7 \mathbf{j}$, vide infra) the observed NOE corresponds to the interaction of $\mathrm{H}-3 \mathrm{a}$ and $\mathrm{H}-5$. Consequently, these hydrogen atoms will be at the same face of the molecule.

$\mathrm{X}$-ray analysis of optically pure $(3 \mathrm{a} R, 5 R)-\mathbf{5 j} \mathbf{j}^{15}$ obtained upon ring closure of optically pure $(S)-4 \mathbf{j}$, indicated that in $5 \mathbf{j}\left(\mathrm{R}^{2}=\mathrm{CH}_{2} \mathrm{OCH}_{3}\right)$, the methoxymethyl group at the bridgehead (C-3a) and the methyl group at the newly created asymmetric center (C-5) are trans.

The structure of $7 \mathbf{j}\left(\mathrm{R}^{2}=\mathrm{CH}_{2} \mathrm{OCH}_{3}\right)$ was determined, inter alia, by ${ }^{1} \mathrm{H}$ NOE difference spectroscopy, which showed that the hydrogen atoms at C-3a and at C-5 are in cis position (Chart III). ${ }^{16}$ The relative configuration of the hydrogen atoms at the three asymmetric centers in $7 \mathbf{j}$ is all cis as was proven by X-ray analysis. ${ }^{17}$ Compund $6 \mathbf{j}$ differs from $7 \mathbf{j}$ in the (relative) position of the hydrogen atom at $\mathrm{C}-1$, in relation to those at $\mathrm{C}-3 \mathrm{a}$ and $\mathrm{C}-6$. The hydrogen atoms at C-3a and C-6 in $6 \mathbf{j}$ are also cis as was confirmed by ${ }^{1} \mathrm{H}$ NOE difference spectroscopy (Chart III). Noticeable is the enhancement of the aromatic hydrogen atom at $\mathrm{C}-9$ in $6 \mathbf{j}$ when $\mathrm{H}-1$ was irradiated $(6 \%$ NOE). In $7 \mathbf{j}$ this aromatic proton $(\mathrm{H}-9)$ increased by $12 \%$ on irradiation of one of the methylene protons (at $\delta 3.57$ ) of the $\mathrm{CH}_{2} \mathrm{OCH}_{3}$ group.

This strong interaction of one of the methylene protons with the aromatic proton in $7 \mathbf{j}$ corresponds to a striking effect on the pattern of absorptions in the ${ }^{1} \mathrm{H}$ NMR spectrum of these protons. Both protons exhibit a doublet of a doublet (dd) instead of an ABX-pattern as in $6 \mathbf{j}$.

The major isomer with a hydrogen atom at the bridgehead carbon atom isolated by cyclization of $4 \mathbf{n}$ exhibits identical characteristic absorptions in the ${ }^{1} \mathrm{H}$ NMR spectrum as $6 \mathrm{~g}$ (see the Experimental Section). ${ }^{1} \mathrm{H}$ NOE difference spectroscopy pointed out that the hydrogen atoms at the bridgehead carbon atom and at the benzylic position are at the same face of the molecule. On irradiation of $\mathrm{H}-4 \mathrm{a}$ a NOE of $8 \%$ was noticed at $\mathrm{H}-6$, and

(15) Nijhuis, W. H. N.; Verboom, W.; Abu El-Fadl, A.; van Hummel, G. J.: Reinhoudt, D. N. J. Org. Chem., following paper in this issue

(16) Irradiation of $\mathrm{H}-1$ of $7 \mathrm{j}$ gave no NOE at $\mathrm{H}-3 \mathrm{a}$, and reverse, no effect was measured at $\mathrm{H}-1$ by irradiation of $\mathrm{H}-3 \mathrm{a}$. This is a general feature of the pyrroloquinolines described here $[\mathbf{b}-7(\mathbf{a}-\mathbf{c}, \mathbf{h}-\mathbf{j}$, and $\mathbf{o}-\mathbf{q})]$. This also goes up in the case of the benzoquinolizine compounds [5-7(d-g and $\mathbf{k}-\mathbf{n})$.

(17) The relative configuration of $7 \mathbf{j}$ has been determined by $\mathrm{X}$-ray analysis of the optically pure $[1 S-(1 \alpha, 3 \mathrm{a} \beta, 5 \alpha)]$-compound..$^{15}$

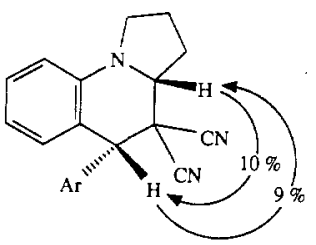

so
Chart IV

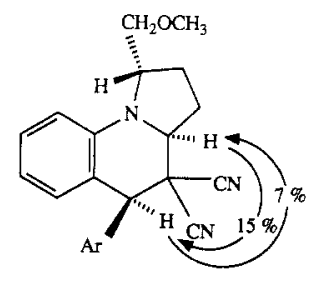

69

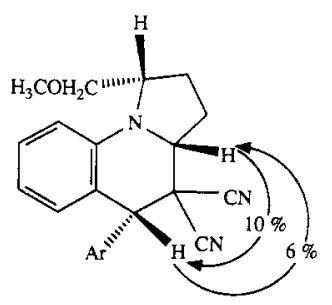

$7 \mathbf{q}$

reverse, upon irradiation of H- 6 the same enhancement was measured at H-4a. Definite proof of the structure of the major isomer was given by X-ray analysis. This proved that $\mathrm{H}-1$ is trans to $\mathrm{H}-4 \mathrm{a}$ and $\mathrm{H}-6$ (Figure 1). We therefore assign structure $6 \mathrm{n}$ to the major isomer.

Cyclization of the in Situ Generated 4o-q $\left(R^{1}=\right.$ 4- $\left.\mathrm{C}_{6} \mathrm{H}_{4} \mathrm{CH}_{3}\right)$. Ring closure of $4 \mathrm{o}\left(\mathrm{R}^{1}=\mathrm{H}\right)$, generated in situ from 30 and malononitrile, in refluxing 1-butanol, resulted in a mixture of two isomers, 50 and 80 , in a total yield of $86 \%$ (ratio $82: 18$ ). The benzylic protons of these two isomers showed different absorptions in the ${ }^{1} \mathrm{H}$ NMR spectrum at $\delta 4.55$ (5o, major isomer) and $\delta 4.68$ (8o, minor isomer), respectively.

A mixture of four diastereomers was obtained by cyclization of $4 \mathrm{p}\left(\mathrm{R}^{2}=\mathrm{CH}_{3}\right)$, prepared in situ from 3p and malononitrile. In this reaction, one compound with the substituent $\mathrm{R}^{2}\left(=\mathrm{CH}_{3}\right)$ at the bridgehead carbon atom, is formed in excess $\left[5 \mathrm{p} ;{ }^{1} \mathrm{H}\right.$ NMR $\delta 1.39\left(\mathrm{~s}, \mathrm{CH}_{3}\right), 4.52[\mathrm{~s}$, $\left.\operatorname{ArCH}\left(4-\mathrm{C}_{6} \mathrm{H}_{4} \mathrm{CH}_{3}\right)\right]$ ]. One of the minor isomers also was a compound with the methyl group at the bridgehead carbon atom $\left[8 \mathrm{p} ;{ }^{1} \mathrm{H}\right.$ NMR $\delta 1.37\left(\mathrm{~s}, \mathrm{CH}_{3}\right), 4.72[\mathrm{~s}, \mathrm{ArCH}-$ $\left.\left(4-\mathrm{C}_{6} \mathrm{H}_{4} \mathrm{CH}_{3}\right)\right]$ ]. Total yield of these two compounds: $76 \%$ (ratio >98:2). The other two isomers, compounds with a hydrogen atom at the bridgehead carbon atom, were formed in a total yield of $22 \%(6 \mathbf{p}$ and $7 \mathbf{p})$. In the ${ }^{1} \mathrm{H}$ NMR spectrum they exhibit different absorptions: $\delta 1.28$ (d, $\left.J=6.3 \mathrm{~Hz}, \mathrm{CH}_{3}\right), 4.55\left[\mathrm{~s}, \mathrm{ArCH}\left(4-\mathrm{C}_{6} \mathrm{H}_{4} \mathrm{CH}_{3}\right)\right]$ and 1.32 (d, $\left.J=6.2 \mathrm{~Hz}, \mathrm{CH}_{3}\right), 4.58$ [s, $\mathrm{ArCH}\left(4-\mathrm{C}_{6} \mathrm{H}_{4} \mathrm{CH}_{3}\right)$ ], and they were formed in a ratio of 7:5. Unfortunately, we were not able to determine which absorptions correspond to $6 \mathbf{p}$ and which to $\mathbf{7 p}$.

Upon ring closure of $4 \mathbf{q}\left(\mathrm{R}^{2}=\mathrm{CH}_{2} \mathrm{OCH}_{3}\right)$, generated in situ from 3q and malononitrile, three pairs of products were formed. Firstly, a mixture of two compounds with the substituent $\mathrm{R}^{2}$ (a methoxymethyl group) at the bridgehead carbon atom (5q and $\mathbf{8 q}$ ) was obtained. These compounds exhibit in the ${ }^{1} \mathrm{H}$ NMR spectrum singlets for the benzylic protons at $\delta 4.56$ and 4.84 , respectively, and they are formed in a ratio of 95:5 (total yield 16\%). Secondly, two mixtures of two isomers could be isolated in total yields of $41 \%(\mathbf{6 q}$ and $\mathbf{9 q}$, ratio $96: 4)$ and $15 \%$ (7q and $10 \mathrm{q}$, ratio $97: 3$ ), respectively. Both isomer mixtures exhibit different absorptions in the ${ }^{1} \mathrm{H}$ NMR spectrum for the hydrogen atom at $\mathrm{C}-5$, the major isomers, $6 \mathbf{q}$ and $\mathbf{7 q}$, 
give singlets at $\delta 4.54$ and 4.58 , while the minor isomers, $\mathbf{9 q}$ and $10 \mathrm{q}$, absorb at lower field, viz. $\delta 4.62$ and 4.72 , respectively.

The structures of $50\left(\mathrm{R}^{2}=\mathrm{H}\right)$ and $\mathbf{5 p}\left(\mathrm{R}^{2}=\mathrm{CH}_{3}\right)$ were proven by ${ }^{1} \mathrm{H}$ NOE difference spectroscopy. Compound 5o $\left(\mathrm{R}^{2}=\mathrm{H}\right)$ could be obtained pure by fractional crystallization, and the cis relationship between the hydrogen atoms at the bridgehead carbon atom (C-3a) and at C-5 was determined by ${ }^{1} \mathrm{H}$ NOE difference spectroscopy (Chart IV). Consequently, in the minor isomer (80), H-3a and $\mathrm{H}-5$ are related trans. The absorption of $\mathrm{H}-5$ of the two isomers in the ${ }^{1} \mathrm{H}$ NMR spectrum is very significant: in 5o $\mathrm{H}-5$ absorbs at higher field $(\delta 4.55)$ than in $80(\delta 4.68)$. This is a general feature of the compounds with $\mathrm{R}^{1}=$ 4- $\mathrm{C}_{6} \mathrm{H}_{4} \mathrm{CH}_{3}$ (vide infra, assignment of $6 q$ and $7 q$ ).

Compound 5p $\left(\mathrm{R}^{2}=\mathrm{CH}_{3}\right)$, the major isomer obtained by cyclization of $4 \mathbf{p}$, could also be isolated pure by fractional crystallization. On basis of the absorption of the benzylic proton, we have assigned the structure 5p. Compound $8 p$ was obtained as a mixture together with the two regioisomers with a hydrogen atom at C-3a. On basis of the absorptions of the benzylic protons of these two compounds we have assigned the structures $6 \mathbf{p}$ and $7 \mathbf{p}$ to these isomers.

The major isomer with the methoxymethyl group at the bridgehead carbon atom, obtained by cyclization of $\mathbf{4 q}$, could be obtained pure by fractional crystallization. On basis of ${ }^{1} \mathrm{H}$ NMR absorptions, in particular the absorption of the benzylic proton ( $\mathrm{H}-5)$, structure $5 q$ was assigned to this compound. The major isomers $(6 \mathbf{q}$ and $7 \mathbf{q})$ of the two isomeric mixtures subsequently isolated could be obtained pure by fractional crystallization, and ${ }^{1} \mathrm{H}$ NOE difference spectroscopy pointed out that the hydrogen atoms at $\mathrm{C}-3 \mathrm{a}$ and at $\mathrm{C}-5$, in both compounds, are at the same face of the molecule (Chart IV). Also, in these compounds, 6q and $\mathbf{7 q}, \mathrm{H}-5$ absorbs at higher field than in the minor isomers $9 q$ and $10 q$. The methylene protons of the $\mathrm{CH}_{2} \mathrm{OCH}_{3}$ group of $6 \mathbf{q}$ reveals the same characteristic ABX pattern in the ${ }^{1} \mathrm{H}$ NMR spectrum as compounds $6 \mathrm{c}\left(\mathrm{R}^{1}\right.$ $=\mathrm{H})$ and $6 \mathrm{j}\left(\mathrm{R}^{1}=\mathrm{CH}_{3}\right)$. The absorptions of the corresponding protons in $\mathbf{7 q}$ show a different specific pattern and can be compared with that of the compounds $7 \mathbf{c}$ and $\mathbf{7 j}$. Therefore, the structures $\mathbf{6 q}$ and $\mathbf{7 q}$ were assigned to these two compounds.

\section{Discussion}

The thermal isomerization of the compounds 4 to the substituted pyrroloquinolines and benzoquinolizines 5-10 proceeds via a 1,5-hydrogen shift followed by subsequent cyclization. ${ }^{18}$

When $\mathrm{R}^{1}=\mathrm{R}^{2}=\mathrm{H}$ the compounds $4 \mathrm{a}(\mathrm{X}=-)$ and $4 \mathrm{~d}$ $\left(\mathrm{X}=\mathrm{CH}_{2}\right.$ ) can only give the ring closed products $\mathbf{5 a}$ and $5 d$, respectively. When $R^{2}$ is a methyl $(4 b, 4 e)$ or an ethyl group (4f), the cyclized product with the substituent $\mathrm{R}^{2}$ at the bridgehead carbon atom is formed selectively $(\mathbf{5 b}$, $5 e$, and $\mathbf{5 f}$, respectively). This is due to a more effective stabilization of a tetrasubstituted iminium double bond

(18) The crucial step in the mechanism is the transfer of hydrogen We have always assumed that the thermal isomerizations of the compounds $4 \mathbf{a}-\mathbf{q}$ to the substituted pyrroloquinolines and benzoquinolizines proceeds via a concerted suprafacial 1,5-hydrogen shift followed by subsequent cyclization. 2,3 A concerted suprafacial hydrogen transfer explains the discrete chirality in the product molecules, ${ }^{15}$ and the primary isotope effect and solvent effect are supporting this. However, on basis of recent experiments we cannot exclude a direct intramolecular transfer of hy drogen with a partial negative charge ${ }^{19}$ when the $\mathrm{NCH}_{2}$ or $\mathrm{NCHR}^{1}$ unit is in the proximity of the dicyanovinyl moiety. The hydrogen transfer may be an intramolecular variant of a Meerwein-Ponndorf-Verley reaction. In literature, there are precedences of such base-catalyzed in tramolecular hydride transfers. ${ }^{20,21}$

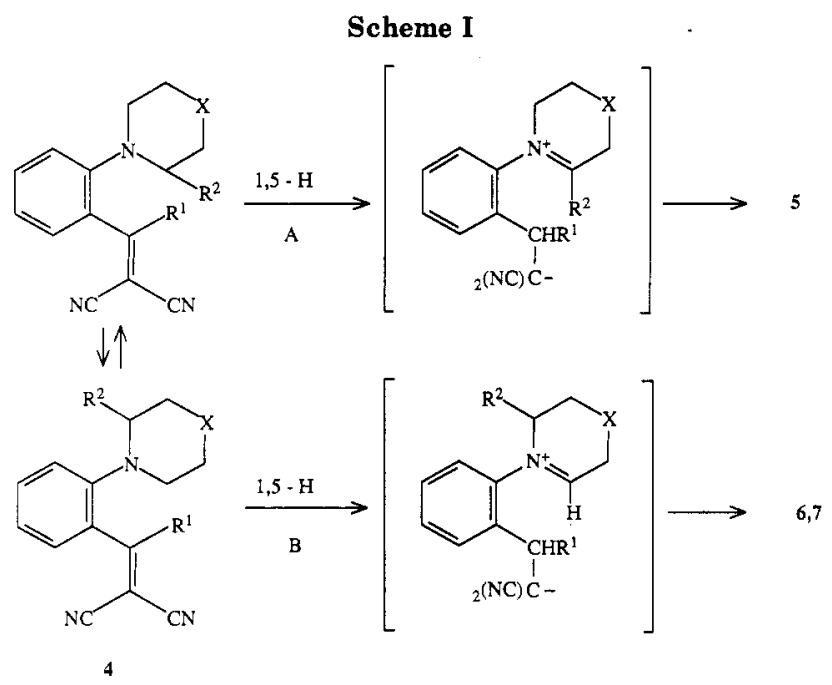

in the dipolar intermediate (A, Scheme I), generated when the hydrogen atom at the substituted carbon atom undergoes a 1,5-hydrogen shift, in comparison with a trisubstituted double bond (B, Scheme $I)$, generated when one of the $\alpha$-methylene protons of the other carbon atom is transferred.

Therefore $\mathrm{C}-\mathrm{C}$ bond formation will take place selectively at the carbon atom bearing the substituent $R^{2}$.

When $\mathrm{R}^{2}$ is a methoxymethyl group, a sterically more hindering group and one that stabilizes the iminium double bond less compared with a methyl (or ethyl) group because of the inductive electron-withdrawing effect of the oxygen atom, the regioselectivity is lost. Consequently, the 1,5hydrogen shift will not take place exclusively from the carbon atom adjacent to nitrogen bearing the methoxymethyl substituent, and mixtures of regioisomers $(5,6$, and 7) are formed.

Cyclization of $4 h-n$, in which $R^{1}$ is a methyl group, gave additional information about the mechanism. The structure of $\mathbf{5 i}\left(\mathrm{X}=-; \mathrm{R}^{1}=\mathrm{R}^{2}=\mathrm{CH}_{3}\right)$ and $\mathbf{5 l}\left(\mathrm{X}=\mathrm{CH}_{2}\right.$; $\mathrm{R}^{1}=\mathrm{R}^{2}=\mathrm{CH}_{3}$ ), for instance, that are formed selectively by reaction of $4 \mathbf{i}$ and $\mathbf{4 l}$ revealed that the hydrogen atom in the product molecule which underwent a 1,5-hydrogen shift is related cis to the substituent $R^{2}$. This was confirmed recently by the formation of one of the enantiomers of $\mathbf{5 j}$ and the subsequent X-ray analysis of a bromo derivative. ${ }^{15}$

The position of the vinyl moiety in 4 determines the stereochemistry of 5,6, and 7. X-ray analysis of $4 a$ showed that the $\beta$-carbon atom of the vinyl moiety of this molecule points away from the amine ring. ${ }^{19}$ Important for the hydrogen shift to take place is the proximity of the migrating hydrogen of the $\mathrm{NCHR}^{2}$ moiety to the $\alpha$-carbon atom of the vinyl moiety, when 5 is formed, or from the $\mathrm{NCH}_{2}$ moiety when 6 and 7 are formed.

When the hydrogen atom attached to the carbon atom with the substituent $R^{2}$ is transferred (and compounds 5 are formed), it takes place from the conformer in which the $\beta$-carbon atom of the vinyl moiety is below the plane of the aromatic ring (Scheme II). It seems likely that the hydrogen migration takes place suprafacially. As the vinyl moiety is already rotated when this hydrogen is migrating, subsequent rotation of the former vinyl group will probably

(19) Groenen, L. C.; Verboom, W.; Nijhuis, W. H. N.; Reinhoudt, D. N.; van Hummel, G. J.; Feil, D. Tetrahedron 1988, 44, 4637.

(20) Warnhof, E. W. Can. J. Chem. 1977, 55, 1635 and references cited therein.

(21) Menicagli, R.; Giacomelli, G. P.; Lardicci, L. J. Organomet. Chem. $1973,50, \mathrm{C} 15$. 
Scheme II<smiles>CC(C)C(C)C1c2ccccc2N2CCC[C@@]12C</smiles><smiles>C[As](C)(C)C</smiles>

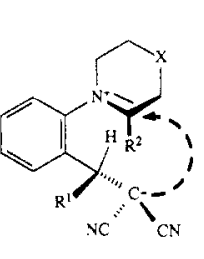

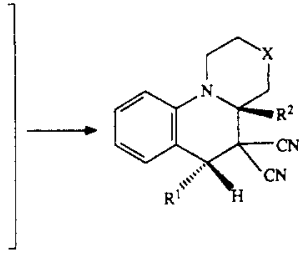

$+$<smiles>CC(C)=C(C)C1C=CC=CC1N1CC(C)(C)CCCC1(C)C</smiles><smiles>CC(C)(C)C</smiles>

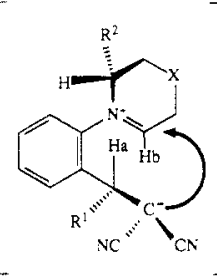

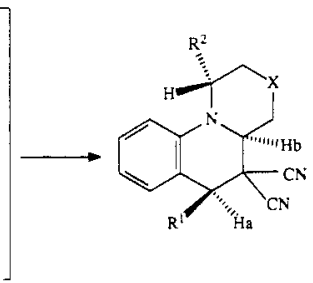

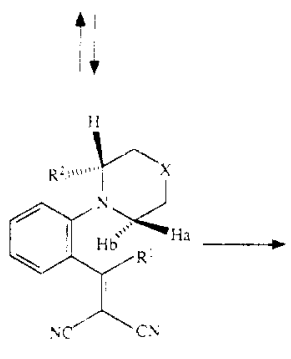

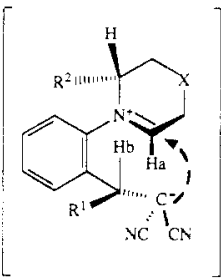

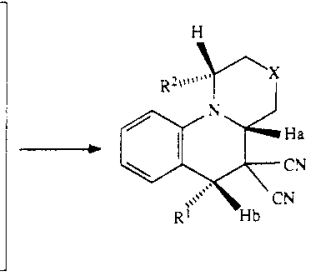

continue in the same direction to enable $\mathrm{C}-\mathrm{C}$ bond formation. The complete reaction is thus stereochemically well defined. Hence, compounds 5 are formed in which the substituent $R^{2}$ at the bridgehead is at the same face of the molecule as the hydrogen atom that has shifted.

In the compounds 6 and 7 the hydrogen atom at the bridgehead and the hydrogen which is transferred are at the same face of the molecule. From these results we conclude that in the dipolar intermediates the carbanion adds to the iminium double bond from the same face as where the hydrogen atom, which underwent a 1,5-shift, originally was located.

The configurations of $6 \mathbf{c}$ and $7 \mathbf{c}$ differ in the position of the hydrogen atom at C-3a related to the hydrogen atom located at the carbon atom bearing the methoxymethyl group (C-1). Because the shift of $\mathrm{Ha}$ and $\mathrm{Hb}$, which determines the ratio of $6 \mathrm{c}$ and $7 \mathrm{c}$, takes place in almost equal ratio, $6 \mathrm{c}$ and $7 \mathrm{c}$ are formed in a ratio of $\approx 1: 1$.

In the formation of $6 \mathbf{j}$ and $7 \mathbf{j}$ one of the two hydrogen atoms, $\mathrm{Ha}$ or $\mathrm{Hb}$, respectively, undergoes a 1,5-hydrogen shift. However, these shifts are not proceeding in a $1: 1$ ratio. CPK models reveal that in $\mathbf{4 j}$, when $\mathrm{Ha}$ or $\mathrm{Hb}$ migrates, the pyrrolidinyl ring is out of plane with the phenyl group because of steric hindrance caused by the substituent $\mathrm{R}^{1}$ (in this case a methyl group). When $\mathrm{Hb}$ is transferred, and $\mathbf{7 j}$ is formed, there is severe steric hindrance between the methoxymethyl group and the aromatic ring. In the product molecule $7 \mathbf{j}$, the methoxymethyl group and H-9 are in close proximity, as was determined by ${ }^{1} \mathrm{H}$ NOE difference spectroscopy (vide supra). The steric hindrance between the methoxymethyl group and $\mathrm{H}-9$ is much less in the case of $\mathrm{Ha}$ shifts, and $6 \mathbf{j}$ is formed. Since the 1,5-hydrogen shift is the rate-determining step, the product ratio of $6 \mathbf{j}$ and $7 \mathbf{j}$ is determined
Scheme III
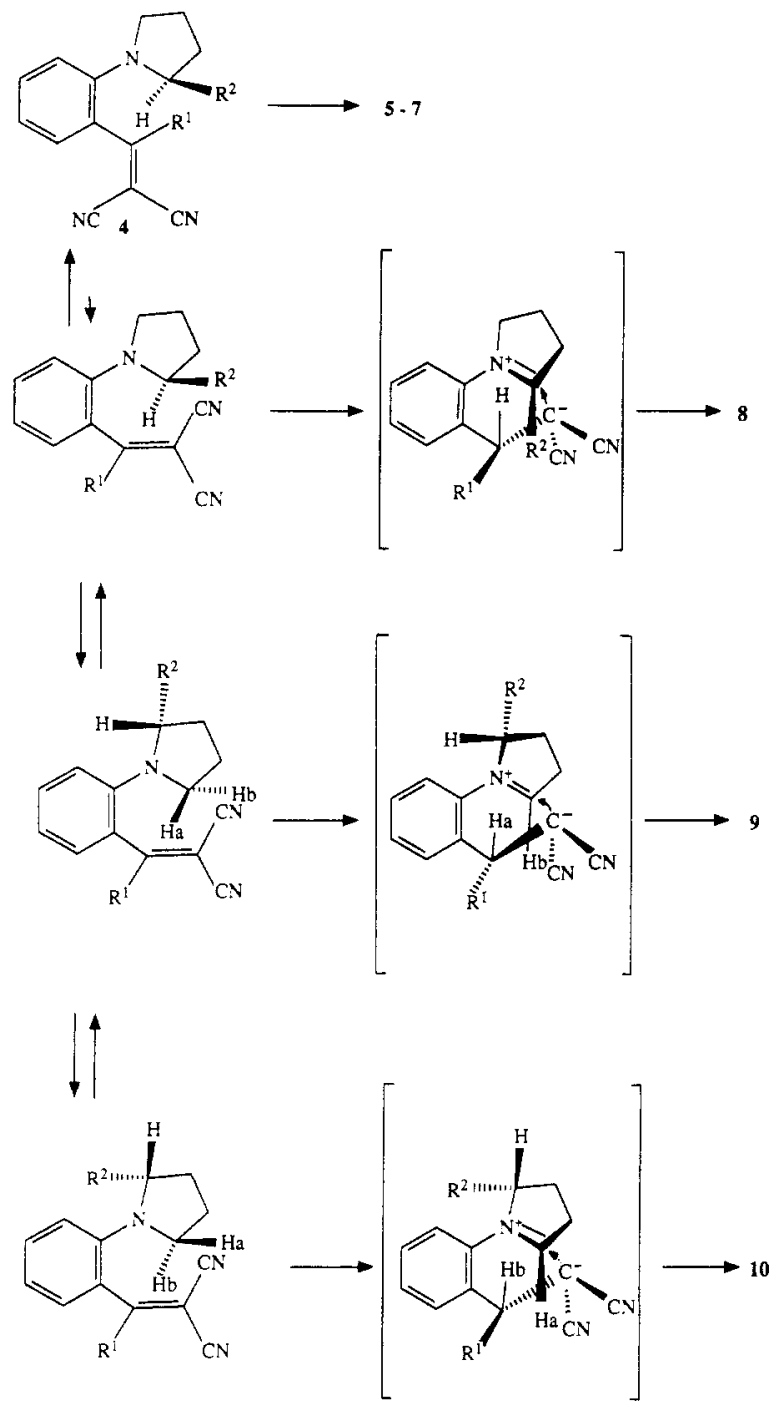

by the ratio of shifts of $\mathrm{Ha}$ and $\mathrm{Hb}$, and so $\mathbf{6 j}$ is formed favorably.

When $R^{1}$ is larger, as is the case in the formation of $6 q$ and $7 \mathbf{q}$ (when $\mathrm{R}^{1}=4-\mathrm{C}_{6} \mathrm{H}_{4} \mathrm{CH}_{3}$ ), the increased steric hindrance causes the pyrrolidinyl ring with the methoxymethyl group to turn even more out of the plane with the aromatic ring, compared with the formation of $\mathbf{6 j}$ and $7 \mathbf{j}$. As a result, the hindrance between the $\mathrm{CH}_{2} \mathrm{OCH}_{3}$ group and the aromatic ring, when $\mathrm{Hb}$ is transferred, and $\mathbf{7 q}$ is formed, is much less than in the formation of $7 \mathbf{j}$. The ratio of $6 q: 7 q$ will therefore decrease compared with that of $6 \mathbf{j}: 7 \mathbf{j}$. The total yield of $\mathbf{6 q}$ and $7 q$ exceeds that of $6 \mathbf{j}$ and $\mathbf{7 j}$ because of the increased steric hindrance between the substituents $R^{1}$ and $R^{2}$.

As was mentioned, the cyclization of $4 \mathbf{a}-\mathbf{n}$ takes place in a stereochemically well defined way, resulting in the formation of compounds 5-7 with the hydrogen or the substituent $R^{1}$ at the bridgehead at the same face of the molecule as the hydrogen that is transferred. However, the cyclization of 4o-q when $R^{1}$ is a 4-methylphenyl group gives besides 5-7(o-q) also the compounds 8-10(o-q), which have the opposite configuration at C-5. When $R^{1}$ is a methyl grcup or a hydrogen, no trace of these products, in which $\mathrm{H}-3 \mathrm{a}$ and $\mathrm{H}-5$ are at the opposite face of the molecule, could be detected. We can explain this result by assuming that there is an interchange of the position of the vinyl group (Scheme III), because of steric hindrance caused by the substituent $\mathrm{R}^{1}$ at the $\alpha$-position of the amine 
ring. Cyclization then partly takes place from the conformation in which the 4-methylphenyl group points away from the amine ring (Scheme III). In this situation, hydrogen migration leads to the formation of an intermediate with a new asymmetric center that has the opposite configuration compared with the intermediates generated by formation of 5-7. Attack of the generated carbanion from the side the hydrogen was transferred gives the compounds 8-10. The bridgehead asymmetric center has the same configuration as in the products 5-7; the new asymmetric center at C-5, however, has the opposite configuration. So, in the case of cyclization of $\mathbf{4 0 - q}$, the geometry of the transition state is less well defined.

In conclusion, we have demonstrated that by proper choice of the substituents $R^{1}$ and $R^{2}$ we can direct the regio- and stereoselectivity in the formation of pyrrolo$[1,2-a]$ quinolines and benzo[c]quinolizines via the "tertamino effect". When $R^{1}$ and $R^{2}$ are substituents like a hydrogen atom or a methyl group, the cyclization proceeds regioselectively. Substituents $\left(R^{2}\right)$, like a methoxymethyl group, that are sterically more hindering and less stabilizing disturb the regioselectivity. The size of the substituent $\mathrm{R}^{1}$ determines the relative configuration of the substituents at the bridgehead carbon atom and at the benzylic position in the product molecule because it directs the position of the vinyl moiety in the starting material.

\section{Experimental Section}

Melting points were determined with a Reichert melting point apparatus and are uncorrected. ${ }^{1} \mathrm{H}$ NMR spectra $\left(\mathrm{CDCl}_{3}\right)$ were recorded with a Bruker WP-80 or a Nicolet NT 200-WB spectrometer $\left(\mathrm{Me}_{4} \mathrm{Si}\right.$ as an internal standard). ${ }^{13} \mathrm{C}$ NMR spectra $\left(\mathrm{CDCl}_{3}\right)$ were recorded with a Nicolet NT 200-WB spectrometer $\left(\mathrm{Me}_{4} \mathrm{Si}\right.$ as an internal standard). Mass spectra were recorded with a Varian Mat 311A spectrometer and IR spectra with a PerkinElmer 257 spectrophotometer. Elemental analyses were carried out by A. Christenhusz of the Laboratory of Chemical Analysis of the University of Twente.

2-Fluorobenzaldehyde (1a) (Janssen), 2-fluoroacetophenone (1b) (Janssen), pyrrolidine (2a) (Merck), 2-methylpyrrolidine (2b) (Alfa), piperidine (2d) (Merck), 2-methylpiperidine (2e) (Merck), and 2-ethylpiperidine (2f) (Merck) were used without further purification.

( \pm )-(2-Methoxymethyl)pyrrolidine (2c) was obtained from L-proline via a racemization to DL-prolin $\mathrm{e}^{22}$ and subsequent conversion to ( \pm )-(2-methoxymethyl)pyrrolidine as described by Enders et al. ${ }^{23}( \pm)$-(2-Methoxymethyl)piperidine (2g) was obtained from $( \pm$ )-2-(hydroxymethyl)piperidine via the same route as was used for the conversion of DL-proline to $( \pm$ )-2-(methoxymethyl)pyrrolidine. ${ }^{23}$

All reactions were carried out under a nitrogen atmosphere.

2-Fluoro-4'-methylbenzophenone (1c). To a solution of (4-methylphenyl)magnesium bromide in diethyl ether $(0.65 \mathrm{M}$; $500 \mathrm{~mL}$ ) was added a solution of 2-fluorobenzaldehyde (1a; 25.0 g; $0.2 \mathrm{~mol})$ in diethyl ether $(250 \mathrm{~mL})$ at such a rate that the temperature in the flask stayed between -10 and $-5{ }^{\circ} \mathrm{C}$. The mixture was allowed to warm to room temperature and was stirred for $2 \mathrm{~h}$. The crude reaction mixture was added to a saturated $\mathrm{NH}_{4} \mathrm{Cl}$ solution $(400 \mathrm{~mL})$. After separation of the organic phase, the water layer was extracted with diethyl ether $(2 \times 200 \mathrm{~mL})$. The combined organic layers were dried $\left(\mathrm{MgSO}_{4}\right)$. The solvent was removed under reduced pressure, and the residue was purified by column chromatography $\left(\mathrm{SiO}_{2} ; \mathrm{CH}_{2} \mathrm{Cl}_{2}\right)$ to give the alcohol as an oil in $75 \%$ yield: ${ }^{1} \mathrm{H}$ NMR $\delta 7.65-6.9(\mathrm{~m}, 8 \mathrm{H}, \mathrm{Ar} \mathrm{H}), 6.11$ [d, $1 \mathrm{H}, J=4.0 \mathrm{~Hz}, \mathrm{CH}(\mathrm{OH})], 2.32\left(\mathrm{~s}, 3 \mathrm{H}, \mathrm{CH}_{3}\right), 2.22[\mathrm{~d}, 1 \mathrm{H}, J=$ $4.0 \mathrm{~Hz}, \mathrm{CH}(\mathrm{OH})$ ]; ${ }^{18} \mathrm{C} \mathrm{NMR} \delta 159.7\left(\mathrm{~d}, J_{\mathrm{C}-\mathrm{F}}=245.7 \mathrm{~Hz}, \mathrm{Ar} \mathrm{CF}\right.$ ), 138.1 and 137.3 ( $\mathrm{s}, \mathrm{Ar}$ C), 131.0 (d, $J_{\mathrm{C}-\mathrm{F}}=12.2 \mathrm{~Hz}, \mathrm{C}-1$ ), 129.1 , 128.7, 127.4, 126.3, and 124.1 (d, $\mathrm{ArC}$ ), $115.0\left(\mathrm{~d}, J_{\mathrm{C}-\mathrm{F}}=21.5 \mathrm{~Hz}\right.$,

(22) Yamada, S.; Hongo, C.; Yoshioka, R.; Chibata, I. J. Org. Chem. $1983,4,843$.

(23) Enders, D.; Eichenauer, H. Chem. Ber. 1979, 112, 2933.
C-3), 69.7 [d, $\mathrm{CH}(\mathrm{OH})$ ], 21.0 (q, $\left.\mathrm{CH}_{3}\right)$; IR $(\mathrm{KBr}) 3350(\mathrm{OH}) \mathrm{cm}^{-1}$; mass spectrum, $m / e 216.095\left(\mathrm{M}^{+}\right.$, calcd for $\mathrm{C}_{14} \mathrm{H}_{13} \mathrm{FO} 216.095$ ).

A solution of the secondary alcohol $(4.33 \mathrm{~g} ; 20 \mathrm{mmol})$ in dry $\mathrm{CH}_{2} \mathrm{Cl}_{2}(15 \mathrm{~mL})$ was added dropwise to a suspension of PCC $(6.47$ g; $30 \mathrm{mmol})$ in dry $\mathrm{CH}_{2} \mathrm{Cl}_{2}(25 \mathrm{~mL})$. The mixture was stirred for $8 \mathrm{~h}$ and subsequently decantated. The solvent was removed under reduced pressure, and the residue was purified by column chromatography $\left(\mathrm{SiO}_{2} ; \mathrm{CH}_{2} \mathrm{Cl}_{2}\right)$ to yield $\mathbf{l c}$ as a solid in a yield of $92 \%$ : mp 74.5-75.5 ${ }^{\circ} \mathrm{C}(\mathrm{MeOH}) ;{ }^{1} \mathrm{H}$ NMR $\delta 7.85-7.0(\mathrm{~m}, 8 \mathrm{H}, \mathrm{Ar}), 2.43$ $\left(\mathrm{s}, 3 \mathrm{H}, \mathrm{CH}_{3}\right) ;{ }^{13} \mathrm{C}$ NMR $\delta 193.0(\mathrm{~s}, \mathrm{C}=0), 159.9\left(\mathrm{~d}, J_{\mathrm{C}-\mathrm{F}}=251.9\right.$ $\mathrm{Hz}, \mathrm{Ar} C F), 144.3$ and 134.8 (s, $\mathrm{ArC}$ ), 132.7, 130.6, 129.9, and 128.1 (d, $\operatorname{Ar}$ C), $127.4\left(\mathrm{~d}, J_{\mathrm{C}-\mathrm{F}}=18.0 \mathrm{~Hz}, \mathrm{C}-1\right), 124.2(\mathrm{~d}, \mathrm{Ar}$ C), 116.2 (dd, $\left.J_{\mathrm{C}-\mathrm{F}}=21.5 \mathrm{~Hz}, \mathrm{C}-3\right), 21.7\left(\mathrm{q}, \mathrm{CH}_{3}\right) ; \mathrm{IR}(\mathrm{KBr}) 1650(\mathrm{C}=0)$ $\mathrm{cm}^{-1}$; mass spectrum, $m / e$ 214.079 $\left(\mathrm{M}^{+}\right.$, calcd 214.079). Anal. Calcd for $\mathrm{C}_{14} \mathrm{H}_{11} \mathrm{FO}\left(M_{\mathrm{r}} 214.240\right)$ : C, 78.49; $\mathrm{H}, 5.18$. Found: C, 78.24; H, 5.11.

General Procedure for the Synthesis of the Benzaldehyde $(3 a-g)$, Acetophenone (3h-n), and Benzophenone Derivatives $(30-q)$. To a solution of 2-fluorobenzaldehyde (1a), 2-fluoroacetophenone (1b), or 2-fluoro-4' ${ }^{\prime}$-methylbenzophenone (1c) (20 $\mathrm{mmol}$ ) and a 2-substituted pyrrolidine or piperidine $(23 \mathrm{mmol})$ in DMF $(20 \mathrm{~mL})$ was added potassium carbonate $(3.18 \mathrm{~g} ; 23$ $\mathrm{mmol}$ ), and the mixture was heated for several hours at $152^{\circ} \mathrm{C}$. When the reaction was complete as followed from TLC, the reaction mixture was allowed to cool. The crude reaction mixture was taken up in water $(100 \mathrm{~mL})$ and extracted with ethyl acetate $(3 \times 75 \mathrm{~mL})$. The combined organic layers were washed with a saturated $\mathrm{NH}_{4} \mathrm{Cl}$ solution $(3 \times 75 \mathrm{~mL})$ and subsequently dried $\left(\mathrm{MgSO}_{4}\right)$. The solvent was removed under reduced pressure, and the residue was purified either by distillation or by column chromatography $\left(\mathrm{SiO}_{2} ; \mathrm{CH}_{2} \mathrm{Cl}_{2}\right)$. For experimental and spectral data, see Table II.

General Procedure for the Condensation of the Compounds $3 a-n$. Synthesis of the 2-Vinyl- $N, N$-dialkylanilines $4 a-n$. To a solution of the aldehydes $3 a-g$ or the ketones $3 h-n$ $(10 \mathrm{mmol})$ in toluene $(10 \mathrm{~mL})$ was added malononitrile $(0.67 \mathrm{~g}$ $10 \mathrm{mmol}$ ) in one portion. After the mixture was stirred for several hours at room temperature, the solvent was removed under reduced pressure. The residue was purified either by crystallization, when solid compounds were obtained, or by column chromatography $\left(\mathrm{SiO}_{2} ; \mathrm{CH}_{2} \mathrm{Cl}_{2}\right)$ when oils were obtained (except for $4 \mathbf{e}$ and 4f, see below). For experimental and spectral data, see Table III.

2-[[2-(2-Methyl-1-piperidinyl) phenyl]methylene]propanedinitrile (4e). After the mixture was stirred for $5 \mathrm{~h}$, the solvent was removed under reduced pressure. The resulting oil could not be crystallized from organic solvents, and slow cyclization took place upon standing. When the oil was passed through a column of silica gel $\left(\mathrm{CH}_{2} \mathrm{Cl}_{2}\right)$ also cyclization took place, affording a mixture of $4 \mathbf{e}$ and $5 e$, which could not be separated. 4e: ${ }^{1} \mathrm{H}$ NMR $\delta 8.39(\mathrm{~s}, 1 \mathrm{H}, \mathrm{CH}=), 8.25-8.05(\mathrm{~m}, 1 \mathrm{H}, \mathrm{Ar} \mathrm{H})$, 7.7-7.45 (m, $1 \mathrm{H}, \mathrm{Ar} \mathrm{H}), 7.3-7.1$ (m, $2 \mathrm{H}, \mathrm{Ar} \mathrm{H}), 3.3-2.6$ (m, $3 \mathrm{H}$, $\left.\mathrm{NCH}_{2}, \mathrm{NCH}\right), 2.05-1.15\left(\mathrm{~m}, 6 \mathrm{H}, \mathrm{CH}_{2}\right), 0.87(\mathrm{~d}, 3 \mathrm{H}, J=6.4 \mathrm{~Hz}$ $\mathrm{CH}_{3}$ )

2-[[2-(2-Ethyl-1-piperidinyl)phenyl]methylene]propanedinitrile (4f). After the mixture was stirred for $28 \mathrm{~h}$, the same procedure was followed as for $4 \mathrm{e}$. A mixture of $4 \mathrm{f}$ and $\mathbf{5 f}$ was obtained, which could not be separated. 4f: ${ }^{1} \mathrm{H}$ NMR $\delta 8.29$ (s, $1 \mathrm{H}, \mathrm{CH}=), 8.25-8.0(\mathrm{~m}, 1 \mathrm{H}, \mathrm{Ar} \mathrm{H}), 7.7-7.4(\mathrm{~m}, 1 \mathrm{H}, \mathrm{Ar} \mathrm{H}), 7.3-6.9$ $(\mathrm{m}, 2 \mathrm{H}, \mathrm{Ar} \mathrm{H}), 3.2-2.6\left(\mathrm{~m}, 3 \mathrm{H}, \mathrm{NCH}_{2}, \mathrm{NCH}\right), 2.1-1.7(\mathrm{~m}, 6 \mathrm{H}$, $\left.\mathrm{CH}_{2}\right), 1.45-1.25\left(\mathrm{~m}, 2 \mathrm{H}, \mathrm{CH}_{2} \mathrm{CH}_{3}\right), 0.70\left(\mathrm{t}, 3 \mathrm{H}, J=7.6 \mathrm{~Hz}, \mathrm{CH}_{3}\right)$.

Cyclization of the Knoevenagel Products $4 a-n$. Synthesis of the Pyrrolo[1,2-a ]quinoline [5-7( $a-c$ and $h-j)]$ and Benzo[c]quinolizine Derivatives [ $[5-7(\mathbf{d}-\mathrm{g}$ and $\mathrm{k}-\mathrm{n})]$. A solution of the condensation product $4(10 \mathrm{mmol})$ in 1-butanol $(10 \mathrm{~mL})$ was heated $\left(118^{\circ} \mathrm{C}\right)$ for several hours until all the starting material had disappeared according to TLC. The solvent was removed under reduced pressure and the residue purified by column chromatography $\left(\mathrm{SiO}_{2} ; \mathrm{CH}_{2} \mathrm{Cl}_{2}\right)$. The reaction times and yields are summarized in Table I.

Reaction of the Benzophenone Derivatives 3o-q with Malononitrile. Synthesis of the Pyrrolo[1,2-a ]quinolines 5-10(o-q). To a solution of the benzophenone derivative $30, \mathbf{p}$, or $\mathbf{q}(10 \mathrm{mmol})$ in 1-butanol $(10 \mathrm{~mL})$ was added malononitrile $(0.67$ $\mathrm{g} ; 10 \mathrm{mmol}$ ). The mixture was heated until all the starting material, including the in situ generated compounds 4, had disappeared according to TLC. The solvent was removed under re- 
Table II. Experimental and Spectral Data of the Aldehydes and Ketones $3^{a}$

\begin{tabular}{|c|c|c|c|c|c|c|c|}
\hline compd & reaction time, $\mathrm{h}$ & yield, \% & $\mathrm{bp},{ }^{\circ} \mathrm{C}(\mathrm{mmHg})$ & $n^{20} \mathrm{D}$ & $\begin{array}{l}\text { mass spectrum, } \\
m / e\left(\mathbf{M}^{+}, \text {calcd }\right)\end{array}$ & ${ }^{1} \mathrm{H}$ NMR, $\delta$ & ${ }^{13} \mathrm{C}$ NMR, $\delta$ \\
\hline $3 \mathbf{b}^{b}$ & 2.5 & 76 & $\begin{array}{c}122-124 \\
\text { (1) }\end{array}$ & 1.5978 & $\begin{array}{c}189.115 \\
(189.115)\end{array}$ & $\begin{array}{c}10.11 \\
(\mathrm{CHO})\end{array}$ & $\begin{array}{c}190.1 \\
(\mathrm{CHO})\end{array}$ \\
\hline $3 c^{c}$ & 2.5 & 81 & $\begin{array}{c}126-129 \\
(0.06)\end{array}$ & 1.5829 & $\begin{array}{c}219.126 \\
(219.126)\end{array}$ & $\begin{array}{c}10.11 \\
(\mathrm{CHO})\end{array}$ & $\begin{array}{c}190.4 \\
(\mathrm{CHO})\end{array}$ \\
\hline $3 e^{d}$ & 16 & 71 & $\begin{array}{c}120-122 \\
(1)\end{array}$ & 1.5563 & $\begin{array}{c}203.131 \\
(203.131)\end{array}$ & $\begin{array}{c}10.52 \\
(\mathrm{CHO})\end{array}$ & $\begin{array}{c}192.4 \\
(\mathrm{CHO})\end{array}$ \\
\hline $3 f^{e}$ & 25 & 52 & $\begin{array}{c}154-156 \\
\text { (1) }\end{array}$ & 1.5583 & $\begin{array}{c}217.148 \\
(217.147)\end{array}$ & $\begin{array}{c}10.42 \\
(\mathrm{CHO})\end{array}$ & $\begin{array}{c}192.2 \\
(\mathrm{CHO})\end{array}$ \\
\hline $3 \mathbf{g}^{\prime}$ & 48 & 58 & $\begin{array}{c}118-120 \\
(0.07)\end{array}$ & 1.5530 & $\begin{array}{c}233.141 \\
(233.142)\end{array}$ & $\begin{array}{c}10.47 \\
(\mathrm{CHO})\end{array}$ & $\begin{array}{c}192.2 \\
(\mathrm{CHO})\end{array}$ \\
\hline $3 \mathbf{i}^{8}$ & 3.5 & 82 & $\begin{array}{c}93-95 \\
(1.6)\end{array}$ & 1.5756 & $\begin{array}{c}203.131 \\
(203.131)\end{array}$ & $\begin{array}{c}2.52 \\
\left(\mathrm{COCH}_{3}\right)\end{array}$ & $\begin{array}{c}202.7 \\
\left(\mathrm{COCH}_{3}\right)\end{array}$ \\
\hline $3 j^{h}$ & 3 & 76 & $\begin{array}{c}137-139 \\
(0.12)\end{array}$ & 1.5614 & $\begin{array}{c}233.141 \\
(233.142)\end{array}$ & $\begin{array}{c}2.54 \\
\left(\mathrm{COCH}_{3}\right)\end{array}$ & $\begin{array}{c}202.6 \\
\left(\mathrm{COCH}_{3}\right)\end{array}$ \\
\hline $3 \mathbf{k}$ & 24 & 52 & $\begin{array}{c}91-92 \\
(0.3)\end{array}$ & 1.5557 & $\begin{array}{c}203.131 \\
(203.131)\end{array}$ & $\begin{array}{c}2.64 \\
\left(\mathrm{COCH}_{3}\right)\end{array}$ & $\begin{array}{c}204.4 \\
\left(\mathrm{COCH}_{3}\right)\end{array}$ \\
\hline $31^{i}$ & 72 & 53 & $\begin{array}{c}98-100 \\
(0.09)\end{array}$ & 1.5398 & $\begin{array}{c}217.147 \\
(217.147)\end{array}$ & $\begin{array}{c}2.65 \\
\left(\mathrm{COCH}_{3}\right)\end{array}$ & $\begin{array}{c}204.1 \\
\left(\mathrm{COCH}_{3}\right)\end{array}$ \\
\hline $3 \mathbf{m}^{j}$ & 84 & 46 & $\begin{array}{c}110-112 \\
(0.1)\end{array}$ & 1.5390 & $\begin{array}{c}231.160 \\
(231.162)\end{array}$ & $\begin{array}{c}2.65 \\
\left(\mathrm{COCH}_{3}\right)\end{array}$ & $\begin{array}{c}204.4 \\
\left(\mathrm{COCH}_{3}\right)\end{array}$ \\
\hline $3 \mathbf{n}^{k}$ & 84 & 45 & $\begin{array}{c}132-134 \\
(0.08)\end{array}$ & 1.5527 & $\begin{array}{c}247.152 \\
(247.157)\end{array}$ & $\begin{array}{c}2.66 \\
\left(\mathrm{COCH}_{3}\right)\end{array}$ & $\begin{array}{c}203.6 \\
\left(\mathrm{COCH}_{3}\right)\end{array}$ \\
\hline 30 & 10 & $\begin{array}{c}81 \\
\text { (oil) }\end{array}$ & & & $\begin{array}{c}265.146 \\
(265.147)\end{array}$ & $\begin{array}{c}2.41 \\
\left(\mathrm{ArCH}_{3}\right)\end{array}$ & $\begin{array}{c}196.6 \\
(\mathrm{C}=\mathrm{O})\end{array}$ \\
\hline $3 \mathbf{p}^{l}$ & 10 & $\begin{array}{c}85 \\
\text { (oil) }\end{array}$ & & & $\begin{array}{c}279.159 \\
(279.162)\end{array}$ & $\begin{array}{c}2.40 \\
\left(\mathrm{ArCH}_{3}\right)\end{array}$ & $\begin{array}{c}197.2 \\
(\mathrm{C}=\mathrm{O})\end{array}$ \\
\hline $3 \mathbf{q}^{m}$ & 12 & $\begin{array}{l}81 \\
\text { (oil) }\end{array}$ & & & $\begin{array}{c}309.173 \\
(309.173)\end{array}$ & $\begin{array}{c}2.36 \\
\left(\mathrm{ArCH}_{3}\right)\end{array}$ & $\begin{array}{c}197.2 \\
(\mathrm{C}=\mathrm{O})\end{array}$ \\
\hline
\end{tabular}

${ }^{a}$ Compounds $3 \mathbf{a}, \mathrm{d}, \mathrm{h}$ are described in ref 2 and 5 . All compounds 3 exhibit in the $\mathrm{IR}$ (KBr) spectrum an absorption between 1645 and 1680 $\mathrm{cm}^{-1}$. ${ }^{b-m}{ }^{1} \mathrm{H}$ NMR $\delta{ }^{b} 1.17\left(\mathrm{~d}, 3 \mathrm{H}, J=5.9 \mathrm{~Hz}, \mathrm{CH}_{3}\right) ;{ }^{c} 3.24\left(\mathrm{~s}, 3 \mathrm{H}, \mathrm{OCH}_{3}\right) ;{ }^{d} 0.92\left(\mathrm{~d}, 3 \mathrm{H}, J=6.3 \mathrm{~Hz}, \mathrm{CH}_{3}\right) ;{ }^{e} 0.70(\mathrm{t}, 3 \mathrm{H}, J=7.2 \mathrm{~Hz}$, $\left.\mathrm{CH}_{2} \mathrm{CH}_{3}\right) ; t_{3.09}\left(\mathrm{~s}, 3 \mathrm{H}, \mathrm{OCH}_{3}\right) ;{ }^{g} 1.15\left[\mathrm{~d}, 3 \mathrm{H}, J=5.6 \mathrm{~Hz}, \mathrm{NCH}\left(\mathrm{CH}_{3}\right)\right] ;{ }^{h} 3.54(\mathrm{ABX}, 1 \mathrm{H}, J=9.1$ and $7.1 \mathrm{~Hz}, \mathrm{CHHOCH}), 3.26(\mathrm{ABX}, 1$ $\mathrm{H}, J=9.3$ and $\left.3.7 \mathrm{~Hz}, \mathrm{CH} H \mathrm{OCH}_{3}\right) ;{ }^{i} 0.84\left[\mathrm{~d}, 3 \mathrm{H}, J=6.1 \mathrm{~Hz}, \mathrm{NCH}\left(\mathrm{CH}_{3}\right)\right] ;{ }^{j} 0.69\left(\mathrm{t}, 3 \mathrm{H}, J=9.0 \mathrm{~Hz}, \mathrm{CH}_{2} \mathrm{CH}_{3}\right) ;{ }^{k} 2.66\left(\mathrm{~s}, 3 \mathrm{H}, \mathrm{CH}_{2} \mathrm{OCH}_{3}\right) ;$ ${ }^{\prime} 1.15\left[\mathrm{~d}, 3 \mathrm{H}, J=6.1 \mathrm{~Hz}, \mathrm{NCH}\left(\mathrm{CH}_{3}\right)\right] ;{ }^{m} 3.55\left(\mathrm{ABX}, 1 \mathrm{H}, J=9.3\right.$ and $\left.7.6 \mathrm{~Hz}, \mathrm{CHHOCH}_{3}\right), 3.15\left(\mathrm{ABX}, 1 \mathrm{H}, J=9.3\right.$ and $\left.3.7 \mathrm{~Hz}, \mathrm{CHHOCH}_{3}\right)$.

Table III. Experimental and Spectral Data of the Knoevenagel Condensation Products 4a-n ${ }^{a}$

\begin{tabular}{|c|c|c|c|c|c|c|}
\hline compd & reaction time, $\mathrm{h}$ & yield, \% & $\mathrm{mp},{ }^{\circ} \mathrm{C}(\mathrm{MeOH})$ & $\begin{array}{l}\text { mass spectrum, } \\
m / e\left(\mathrm{M}^{+}, \text {calcd }\right)\end{array}$ & ${ }^{1} \mathrm{H}$ NMR, $\delta$ & ${ }^{13} \mathrm{C}$ NMR, $\delta$ \\
\hline $4 b^{b}$ & 5 & 86 & $58-60$ & $\begin{array}{c}237.125 \\
(237.127)\end{array}$ & $\begin{array}{c}7.99 \\
=\mathrm{CH})\end{array}$ & $\begin{array}{c}159.0 \\
(=\mathrm{CH})\end{array}$ \\
\hline $4 c$ & 48 & 96 & $77.5-78.5$ & $\begin{array}{c}267.138 \\
(267.137)\end{array}$ & $\begin{array}{l}8.1-7.9 \\
(=\mathrm{CH})\end{array}$ & $\begin{array}{c}159.0 \\
(=\mathrm{CH})\end{array}$ \\
\hline $4 g^{c}$ & 24 & 90 & oil & $\begin{array}{c}281.152 \\
(281.153)\end{array}$ & $\left(\begin{array}{c}8.43 \\
=\mathrm{CH})\end{array}\right.$ & $\begin{array}{c}158.1 \\
(=\mathrm{CH})\end{array}$ \\
\hline $4 h$ & $24^{i}$ & 85 & $111-113$ & $\begin{array}{c}237.127 \\
(237.127)\end{array}$ & $\begin{array}{c}2.58 \\
\left(\mathrm{CH}_{3}\right)\end{array}$ & {$\left[\begin{array}{c}178.5 \\
\left.=\mathrm{C}\left(\mathrm{CH}_{3}\right)\right]\end{array}\right.$} \\
\hline $4 i^{d}$ & $30^{i}$ & 95 & oil & $\begin{array}{c}251.143 \\
(251.142)\end{array}$ & $\begin{array}{c}2.58 \\
\left(\mathrm{CH}_{3}\right)\end{array}$ & {$\left[\begin{array}{l}179.0 \\
\left.=C\left(\mathrm{CH}_{3}\right)\right]\end{array}\right.$} \\
\hline $4 \mathbf{j}^{e}$ & $40^{i}$ & 82 & oil & $\begin{array}{c}281.152 \\
(281.153)\end{array}$ & $\begin{array}{c}2.57 \\
\left(\mathrm{CH}_{3}\right)\end{array}$ & {$\left[\begin{array}{c}179.8 \\
\left.=C\left(\mathrm{CH}_{3}\right)\right]\end{array}\right.$} \\
\hline $4 k$ & 72 & 96 & $96-100$ & $\begin{array}{c}251.141 \\
(251.142)\end{array}$ & $\begin{array}{c}2.67 \\
\left(\mathrm{CH}_{3}\right)\end{array}$ & {$\left[\begin{array}{l}178.7 \\
\left.=C\left(\mathrm{CH}_{3}\right)\right]\end{array}\right.$} \\
\hline $41^{f}$ & 48 & 90 & oil & $\begin{array}{c}265.161 \\
(265.158)\end{array}$ & $\begin{array}{c}2.67 \\
\left(\mathrm{CH}_{3}\right)\end{array}$ & {$\left[\begin{array}{l}178.7 \\
\left.=\mathrm{C}\left(\mathrm{CH}_{3}\right)\right]\end{array}\right.$} \\
\hline $4 m^{8}$ & 48 & 97 & oil & $\begin{array}{c}279.174 \\
(279.174)\end{array}$ & $\begin{array}{c}2.67 \\
\left(\mathrm{CH}_{3}\right)\end{array}$ & {$\left[=C\left(\mathrm{CH}_{3}\right)\right]$} \\
\hline $4 \mathbf{n}^{h}$ & 72 & 96 & oil & $\begin{array}{c}295.168 \\
(295.173)\end{array}$ & $\begin{array}{c}2.67 \\
\left(\mathrm{CH}_{3}\right)\end{array}$ & $\begin{aligned} & 179.8 \\
{[=} & \left.C(\mathrm{CH})_{3}\right]\end{aligned}$ \\
\hline
\end{tabular}

a Compounds $4 \mathrm{a}$ and $\mathbf{4 d}$ are described in ref 2 . All the compounds $\mathbf{4 a - n}$ exhibit in the IR (KBr) spectrum an absorption between 2220 and $2240(\mathrm{CN}) \mathrm{cm}^{-1}$. Satisfactory elemental analyses were obtained for $\mathbf{4 b}, \mathbf{c}, \mathbf{h}, \mathbf{k}(\mathrm{C}, \pm 0.30 ; \mathrm{H}, \pm 0.10 ; \mathrm{N}, \pm 0.30)$. ${ }^{b-h}{ }^{1} \mathrm{H} \mathrm{NMR} \delta{ }^{b} 1.13(\mathrm{~d}, 3 \mathrm{H}, J$ $\left.=6.1 \mathrm{~Hz}, \mathrm{CH}_{3}\right) ;{ }^{c} 3.13\left(\mathrm{~s}, 3 \mathrm{H}, \mathrm{OCH}_{3}\right) ;{ }^{d} 1.16\left[\mathrm{~d}, 3 \mathrm{H}, J=5.9 \mathrm{~Hz}, \mathrm{NCH}\left(\mathrm{CH}_{3}\right)\right] ;{ }^{e} 3.26\left(\mathrm{~s}, 3 \mathrm{H}, \mathrm{OCH}_{3}\right) ;{ }^{\prime} 0.88[\mathrm{~d}, 3 \mathrm{H}, J=6.3 \mathrm{~Hz}, \mathrm{NCH}(\mathrm{CH})]$; ${ }^{8} 0.73\left(\mathrm{t}, 3 \mathrm{H}, J=7.2 \mathrm{~Hz}, \mathrm{CH}_{2} \mathrm{CH}_{3}\right) ;{ }^{h} 3.14\left(\mathrm{~s}, 3 \mathrm{H}, \mathrm{OCH}_{3}\right)$. i Reaction performed at $40^{\circ} \mathrm{C}$.

duced pressure, and the residue was purified by column chromatography $\left(\mathrm{SiO}_{2} ; \mathrm{CH}_{2} \mathrm{Cl}_{2}\right)$. The reaction times and yields are summarized in Table I.

$1,2,3,3 a-T e t r a h y d r o-3 a-m e t h y l p y r r o l o[1,2-a] q u i n o l i n e-$ 4,4(5H)-dicarbonitrile (5b): oil; ${ }^{1} \mathrm{H}$ NMR (80 MHz) $\delta 7.3-6.95$ (m, $2 \mathrm{H}, \mathrm{Ar} \mathrm{H}), 6.85-6.5(\mathrm{~m}, 2 \mathrm{H}, \mathrm{Ar} \mathrm{H}), 3.42\left(\mathrm{~s}, 2 \mathrm{H}, \mathrm{ArCH}_{2}\right.$ ), 3.75-3.2 (m, $\left.2 \mathrm{H}, \mathrm{NCH}_{2}\right), 2.5-2.0\left(\mathrm{~m}, 4 \mathrm{H}, \mathrm{CH}_{2}\right), 1.26\left(\mathrm{~s}, 3 \mathrm{H}, \mathrm{CH}_{3}\right)$; ${ }^{13} \mathrm{C}$ NMR $\delta 141.1$ (s, C-9a), 129.0, 117.2, and 113.2 (d, Ar C), 115.4, 114.3 , and 112.9 (s, C-5a and $\mathrm{CN}$ ), 63.8 [s, $\left.\mathrm{NC}\left(\mathrm{CH}_{3}\right)\right], 47.6(\mathrm{t}$, $\left.\mathrm{NCH}_{2}\right), 38.7$ [s, $\mathrm{C}(\mathrm{CN})_{2}$ ], $37.0\left(\mathrm{t}, \mathrm{ArCH}_{2}\right), 34.4$ and $21.6\left(\mathrm{t}, \mathrm{CH}_{2}\right)$, $20.6\left(\mathrm{q}, \mathrm{CH}_{3}\right) ; \mathrm{IR}(\mathrm{KBr}) 2245(\mathrm{CN}) \mathrm{cm}^{-1}$; mass spectrum, $m / e$
$237.126\left(\mathrm{M}^{+}\right.$, calcd for $\mathrm{C}_{15} \mathrm{H}_{15} \mathrm{~N}_{3}$ 237.127)

1,2,3,3a-Tetrahydro-3a-(methoxymethyl) pyrrolo[1,2-a ]quinoline-4,4(5H)-dicarbonitrile (5c): $\mathrm{mp} 135-136^{\circ} \mathrm{C}(\mathrm{MeOH})$; ${ }^{1} \mathrm{H}$ NMR (80 MHz) $\delta 7.3-7.0$ and 6.9-6.6 (m, $\left.4 \mathrm{H}, \mathrm{Ar} \mathrm{H}\right), 3.75-3.5$ (m, $2 \mathrm{H}, \mathrm{NCH}_{2}$ ), $3.47\left(\mathrm{~s}, 2 \mathrm{H}, \mathrm{ArCH}_{2}\right.$ ), 3.37 (s, $2 \mathrm{H}, \mathrm{CH}_{2} \mathrm{OCH}_{3}$ ), $3.30\left(\mathrm{~s}, 3 \mathrm{H}, \mathrm{OCH}_{3}\right), 2.65-2.0\left(\mathrm{~m}, 4 \mathrm{H}, \mathrm{CH}_{2}\right) ;{ }^{13} \mathrm{C} \mathrm{NMR} \delta 141.4(\mathrm{~s}$, C-9a), 129.1, 129.0, 117.6, and 113.8 ( $\mathrm{d}, \mathrm{Ar} \mathrm{C}), 114.9,114.6$, and 113.7 (s, C-5a and $\mathrm{CN}), 73.7\left(\mathrm{t}, \mathrm{CH}_{2} \mathrm{OCH}_{3}\right), 66.1 \mathrm{~s}, \mathrm{NC}-$ $\left.\left(\mathrm{CH}_{2} \mathrm{OCH}_{3}\right)\right], 59.6\left(\mathrm{q}, \mathrm{OCH}_{3}\right), 48.8\left(\mathrm{t}, \mathrm{NCH}_{2}\right), 36.9\left[\mathrm{~s}, \mathrm{C}(\mathrm{CN})_{2}\right]$, $34.7,33.5$, and $22.3\left(\mathrm{t}, \mathrm{ArCH}_{2}\right.$ and $\left.\mathrm{CH}_{2}\right) ; \mathrm{IR}(\mathrm{KBr}) 2240(\mathrm{CN}) \mathrm{cm}^{-1}$; mass spectrum, $m / e 267.138\left(\mathrm{M}^{+}\right.$, calcd 267.137$)$. Anal. Calcd 
for $\mathrm{C}_{16} \mathrm{H}_{17} \mathrm{~N}_{3} \mathrm{O}\left(M_{\mathrm{r}} 267.331\right): \mathrm{C}, 71.89 ; \mathrm{H}, 6.41 ; \mathrm{N}, 15.72$. Found: C, $72.10 ; \mathrm{H}, 6.73 ; \mathrm{N}, 15.61$.

cis -( \pm )-1,2,3,3a-Tetrahydro-1-(methoxymethyl) pyrrolo[1,2-a ]quinoline-4,4(5H)-dicarbonitrile $(6 \mathrm{c}): \mathrm{mp} 156-158^{\circ} \mathrm{C}$ $(\mathrm{MeOH}) ;{ }^{1} \mathrm{H}$ NMR $(200 \mathrm{MHz}) \delta 7.25-7.1$ and $7.05-7.0(\mathrm{~m}, 2 \mathrm{H}$, Ar H), 6.8-6.7 (m, $2 \mathrm{H}, \mathrm{Ar} \mathrm{H}), 4.2-4.05\left[\mathrm{~m}, 1 \mathrm{H}, \mathrm{NCH}\left(\mathrm{CH}_{2} \mathrm{OCH}_{3}\right)\right]$, 3.91 [dd, $1 \mathrm{H}, J=3.7$ and $8.2 \mathrm{~Hz}, \mathrm{NCH}$ (bridgehead)], 3.53 (ABX, $1 \mathrm{H}, J=9.5$ and $\left.5.2 \mathrm{~Hz}, \mathrm{CH} \mathrm{HOCH}_{3}\right)$ and $3.49(\mathrm{ABX}, 1 \mathrm{H}, J=$ 9.5 and $\left.4.0 \mathrm{~Hz}, \mathrm{CHHOCH}_{3}\right), 3.46\left(\mathrm{~s}, 2 \mathrm{H}, \mathrm{ArCH}_{2}\right), 3.35(\mathrm{~s}, 3 \mathrm{H}$, $\left.\mathrm{OCH}_{3}\right), 2.7-2.5(\mathrm{~m}, 1 \mathrm{H}, \mathrm{CHH}), 2.4-2.2\left(\mathrm{~m}, 2 \mathrm{H}, \mathrm{CH}_{2}\right), 2.05-1.95$ $(\mathrm{m}, 1 \mathrm{H}, \mathrm{CH} H) ;{ }^{13} \mathrm{C}$ NMR $\delta 141.2$ (s, C-9a), 129.3, 129.1, 117.7, and $112.4(\mathrm{~d}, \mathrm{Ar} \mathrm{C}), 115.4$ and $114.6(\mathrm{~s}, \mathrm{CN}), 113.4(\mathrm{~s}, \mathrm{C}-5 \mathrm{a}), 73.5$ (t, $\mathrm{CH}_{2} \mathrm{OCH}_{3}$ ), 62.6 [d, NCH (bridgehead)], 60.3 [d, NCH$\left.\left(\mathrm{CH}_{2} \mathrm{OCH}_{3}\right)\right], 59.3\left(\mathrm{q}, \mathrm{OCH}_{3}\right), 38.2\left(\mathrm{t}, \mathrm{ArCH}_{2}\right), 33.6\left[\mathrm{~s}, \mathrm{C}(\mathrm{CN})_{2}\right]$, 28.5 and $25.9\left(\mathrm{t}, \mathrm{CH}_{2}\right)$; IR $(\mathrm{KBr}) 2250(\mathrm{CN}) \mathrm{cm}^{-1}$; mass spectrum, $m / e$ 267.138 ( $\mathrm{M}^{+}$, calcd 267.137). Anal. Calcd for $\mathrm{C}_{16} \mathrm{H}_{17} \mathrm{~N}_{3} \mathrm{O}\left(M_{\mathrm{r}}\right.$ 267.331): C, 71.89; H, 6.41; N, 15.72. Found: C, 71.97; H, 6.60; $\mathrm{N}, 15.75$.

trans - ( \pm ) -1,2,3,3a-Tetrahydro- 1 -(methoxymethyl)pyrrolo[1,2-a ]quinoline-4,4(5H)-dicarbonitrile $(7 \mathrm{c})$ : $\mathrm{mp}$ $99-101^{\circ} \mathrm{C}(\mathrm{MeOH}) ;{ }^{1} \mathrm{H}$ NMR $(200 \mathrm{MHz}) \delta 7.25-7.15$ and 7.1-7.0 (m, $2 \mathrm{H}$, Ar H) 6.8-6.65 (m, $2 \mathrm{H}$, Ar $\mathrm{H}), 4.1-3.95[\mathrm{~m}, 1 \mathrm{H}$, $\mathrm{NCH}\left(\mathrm{CH}_{2} \mathrm{OCH}_{3}\right)$ ], 3.73 [dd, $1 \mathrm{H}, J=5.2$ and $9.1 \mathrm{~Hz}, \mathrm{NCH}$ (bridgehead)], 3.57 (dd, $1 \mathrm{H}, J=9.4$ and $2.5 \mathrm{~Hz}, \mathrm{CHHOCH}_{3}$ ), 3.55 and $3.44\left(\mathrm{AB} \mathrm{q}, 2 \mathrm{H}, J=16.4 \mathrm{~Hz}, \mathrm{ArCH}_{2}\right), 3.36\left(\mathrm{~s}, 3 \mathrm{H}, \mathrm{OCH}_{3}\right)$, 3.14 (dd, $1 \mathrm{H}, J=9.4$ and $\left.9.4 \mathrm{~Hz}, \mathrm{CH} \mathrm{HOCH}_{3}\right), 2.45-2.35(\mathrm{~m}, 1$ $\mathrm{H}, \mathrm{CHH}), 2.3-2.15\left(\mathrm{~m}, 3 \mathrm{H}, \mathrm{CHH}\right.$ and $\left.\mathrm{CH}_{2}\right) ;{ }^{13} \mathrm{C} \mathrm{NMR} \delta 140.8$ (s, C-9a), 129.3, 128.9, 117.8, and $112.2(\mathrm{~d}, \mathrm{Ar} \mathrm{C}), 114.7$ and 113.1 (s, CN), 114.4 (s, C-5a), $71.7\left(\mathrm{t}, \mathrm{CH}_{2} \mathrm{OCH}_{3}\right), 63.0$ [d, $\mathrm{NCH}$ (bridgehead)], $59.1\left(\mathrm{q}, \mathrm{OCH}_{3}\right), 56.9\left[\mathrm{~d}, \mathrm{NCH}\left(\mathrm{CH}_{2} \mathrm{OCH}_{3}\right)\right], 38.0$ $\left(\mathrm{t}, \mathrm{ArCH}_{2}\right), 34.8\left[\mathrm{~s}, \mathrm{C}(\mathrm{CN})_{2}\right], 27.6$ and $27.0\left(\mathrm{t}, \mathrm{CH}_{2}\right) ; \mathrm{IR}(\mathrm{KBr}) 2250$ (CN) $\mathrm{cm}^{-1}$; mass spectrum, $m / e$ 267.138 $\left(\mathrm{M}^{+}\right.$, calcd 267.137). Anal. Calcd for $\mathrm{C}_{16} \mathrm{H}_{17} \mathrm{~N}_{3} \mathrm{O}\left(M_{\mathrm{r}} 267.331\right) ; \mathrm{C}, 71.89 ; \mathrm{H}, 6.41 ; \mathrm{N}, 15.72$. Found: $\mathrm{C}, 72.04 ; \mathrm{H}, 6.60 ; \mathrm{N}, 15.75$.

2,3,4,4a-Tetrahydro-4a-methyl- $1 H$-benzo [ $c$ ]quinolizine5,5(6 H)-dicarbonitrile (5e): $\mathrm{mp} 131-132{ }^{\circ} \mathrm{C}(\mathrm{MeOH}) ;{ }^{1} \mathrm{H}$ NMR $(80 \mathrm{MHz}) \delta 7.35-6.65(\mathrm{~m}, 4 \mathrm{H}, \mathrm{Ar} \mathrm{H}), 3.9-3.55\left(\mathrm{~m}, 1 \mathrm{H}, \mathrm{NCH}_{\mathrm{sq}} \mathrm{H}_{\mathrm{az}}\right)$, $3.52\left(\mathrm{~s}, 2 \mathrm{H}, \mathrm{ArCH}_{2}\right), 3.0-2.5\left(\mathrm{~m}, 1 \mathrm{H}, \mathrm{NCH}_{\mathrm{eq}} H_{\mathrm{ax}}\right), 2.3-1.5(\mathrm{~m}, 6$ $\left.\mathrm{H}, \mathrm{CH}_{2}\right), 1.23\left(\mathrm{~s}, 3 \mathrm{H}, \mathrm{CH}_{3}\right) ;{ }^{13} \mathrm{C} \mathrm{NMR} 143.7(\mathrm{~s}, \mathrm{C}-10 \mathrm{a}), 129.2,128.8$, 119.0, and 113.4 (d, Ar C), $115.1(\mathrm{~s}, \mathrm{C}-6 \mathrm{a}), 115.0(\mathrm{~s}, \mathrm{CN}), 57.2[\mathrm{~s}$, $\left.\mathrm{NC}\left(\mathrm{CH}_{3}\right)\right], 43.1\left[\mathrm{~s}, \mathrm{C}(\mathrm{CN})_{2}\right], 42.6\left(\mathrm{t}, \mathrm{NCH}_{2}\right), 34.3,24.9$, and 19.4 $\left(\mathrm{t}, \mathrm{CH}_{2}\right), 35.2\left(\mathrm{t}, \mathrm{ArCH}_{2}\right), 13.8\left(\mathrm{q}, \mathrm{CH}_{3}\right) ; \mathrm{IR}(\mathrm{KBr}) 2255(\mathrm{CN}) \mathrm{cm}^{-1}$; mass spectrum, $m / e$ 251.142 ( ${ }^{+}$, calcd 251.142). Anal. Calcd for $\mathrm{C}_{16} \mathrm{H}_{17} \mathrm{~N}_{3}\left(M_{r} 251.332\right)$ : C, 76.46; H, 6.82; N, 16.72. Found: C, $76.39 ; \mathrm{H}, 6.81 ; \mathrm{N}, 16.32$.

2,3,4,4a-Tetrahydro-4a-et hyl- $1 H$-benzo[ $c$ ]quinolizine$\mathbf{5 , 5}(\mathbf{6 H})$-dicarbonitrile (5f): $\mathrm{mp} 132-133.5^{\circ} \mathrm{C}(\mathrm{MeOH}) ;{ }^{1} \mathrm{H}$ NMR (80 MHz) $\delta 7.3-6.95$ (m, $2 \mathrm{H}, \mathrm{Ar} \mathrm{H}), 6.9-6.7$ (m, $2 \mathrm{H}, \mathrm{Ar}), 3.8-3.4$ $\left(\mathrm{m}, 1 \mathrm{H}, \mathrm{NCH}_{\mathrm{eq}} \mathrm{H}_{\mathrm{ax}}\right), 3.51\left(\mathrm{~s}, 2 \mathrm{H}, \mathrm{ArCH}_{2}\right), 3.05-2.7(\mathrm{~m}, 1 \mathrm{H}$, $\left.\mathrm{NCH}_{\mathrm{eq}} H_{\mathrm{az}}\right), 2.55-1.25\left(\mathrm{~m}, 8 \mathrm{H}, \mathrm{CH}_{2}, \mathrm{CH}_{2} \mathrm{CH}_{3}\right), 1.03(\mathrm{t}, 3 \mathrm{H}, J=$ $\left.7.5 \mathrm{~Hz}, \mathrm{CH}_{2} \mathrm{CH}_{3}\right) ;{ }^{13} \mathrm{C}$ NMR $\delta 143.9$ (s, C-10a), 129.0, 128.8, 118.8, and 113.3 (d, Ar C), 115.7, 115.5, and 115.4 (s, C-6a and CN), 59.7 [s, $\left.\mathrm{NC}\left(\mathrm{CH}_{2} \mathrm{CH}_{3}\right)\right], 42.6\left[\mathrm{~s}, \mathrm{C}(\mathrm{CN})_{2}\right], 43.5\left(\mathrm{t}, \mathrm{NCH}_{2}\right), 31.9,24.6$, and $19.6\left(\mathrm{t}, \mathrm{CH}_{2}\right), 34.4\left(\mathrm{t}, \mathrm{ArCH}_{2}\right), 23.1\left(\mathrm{t}, \mathrm{CH}_{2} \mathrm{CH}_{3}\right), 9.3\left(\mathrm{q}, \mathrm{CH}_{2} \mathrm{CH}_{3}\right)$; IR $(\mathrm{KBr}) 2255(\mathrm{CN}) \mathrm{cm}^{-1}$; mass spectrum, $m / e 265.158\left(\mathrm{M}^{+}\right.$, calcd 265.158). Anal. Calcd for $\mathrm{C}_{17} \mathrm{H}_{19} \mathrm{~N}_{3}\left(M_{\mathrm{r}} 265.359\right)$ : C, 76.95; $\mathrm{H}$, $7.22 ; \mathrm{N}, 15.83$. Found: C, 76.74; H, 7.37; N, 15.80 .

2,3,4,4a-Tetrahydro-4a-(methoxymethyl)- $1 H$-benzo[c]quinolizine-5,5(6H)-dicarbonitrile $(5 \mathrm{~g})$ : $\mathrm{mp} 109-110^{\circ} \mathrm{C}$ $(\mathrm{MeOH}) ;{ }^{1} \mathrm{H}$ NMR (200 MHz) $\delta 7.25-7.15$ and $7.1-7.0(\mathrm{~m}, 2 \mathrm{H}$, Ar H), 6.9-6.75 (m, 2 H, Ar H), 3.8-3.65 (m, $\left.1 \mathrm{H}, \mathrm{NCH}_{\mathrm{eq}} \mathrm{H}_{\mathrm{ax}}\right), 3.62$ and $3.37\left(\mathrm{AB} \mathrm{q}, 2 \mathrm{H}, J=10.3 \mathrm{~Hz}, \mathrm{CH}_{2} \mathrm{OCH}_{3}\right), 3.50\left(\mathrm{~s}, 2 \mathrm{H}, \mathrm{ArCH}_{2}\right)$, $3.30\left(\mathrm{~s}, 3 \mathrm{H}, \mathrm{OCH}_{3}\right), 2.9-2.6\left(\mathrm{~m}, 3 \mathrm{H}, \mathrm{NCH}_{\mathrm{eq}} H_{\mathrm{ax}}, \mathrm{CH}_{2}\right), 2.0-1.5(\mathrm{~m}$, $\left.4 \mathrm{H}, \mathrm{CH}_{2}\right) ;{ }^{13} \mathrm{C}$ NMR $\delta 143.7$ (s, C-10a), 129.2, 128.7, and 118.8 (d, Ar C), 115.8 (s, C-6a), 115.6 and 114.7 (s, CN), 112.8 (d, Ar C), $68.0\left(\mathrm{t}, \mathrm{CH}_{2} \mathrm{OCH}_{3}\right), 59.4\left(\mathrm{q}, \mathrm{OCH}_{3}\right), 59.0\left[\mathrm{~s}, \mathrm{NC}\left(\mathrm{CH}_{2} \mathrm{OCH}_{3}\right]\right.$ $43.1\left(\mathrm{t}, \mathrm{NCH}_{2}\right), 41.1\left[\mathrm{~s}, \mathrm{C}(\mathrm{CN})_{2}\right], 34.2\left(\mathrm{t}, \mathrm{ArCH}_{2}\right), 30.3,24.5$, and $19.0\left(\mathrm{t}, \mathrm{CH}_{2}\right) ; \mathrm{IR}(\mathrm{KBr}) 2255(\mathrm{CN}) \mathrm{cm}^{-1}$; mass spectrum, $\mathrm{m} / \mathrm{e}$ $281.150\left(\mathrm{M}^{+}\right.$, calcd 281.152). Anal. Calcd for $\mathrm{C}_{17} \mathrm{H}_{19} \mathrm{~N}_{3} \mathrm{O}\left(M_{\mathrm{r}}\right.$ 281.359): C, 72.57; H, 6.81; N, 14.92. Found: C, 72.29; H, 6.76; $\mathrm{N}, 14.90$.

trans $-( \pm)-2,3,4,4$ a-Tetrahydro-1-(methoxymethyl)-1 $H$ benzo[c]quinolizine-5,5(6H)-dicarbonitrile $(6 \mathrm{~g})$ : $\mathrm{mp}$ 168-170 ${ }^{\circ} \mathrm{C}(\mathrm{MeOH}) ;{ }^{1} \mathrm{H}$ NMR (200 MHz) $\delta$ 7.3-7.15 (m, $\left.1 \mathrm{H}, \mathrm{Ar} \mathrm{H}\right)$ 7.05-6.9 (m, $2 \mathrm{H}, \mathrm{Ar} \mathrm{H}), 6.85-6.7(\mathrm{~m}, 1 \mathrm{H}, \mathrm{Ar} \mathrm{H}), 4.35-4.2[\mathrm{~m}, 1$ $\left.\mathrm{H}, \mathrm{NCH}\left(\mathrm{CH}_{2} \mathrm{OCH}_{3}\right)\right], 3.55(\mathrm{ABX}, 1 \mathrm{H}, J=9.3$ and $9.3 \mathrm{~Hz}$,
$\left.\mathrm{CHHOCH}_{3}\right)$ and $3.37\left(\mathrm{ABX}, 1 \mathrm{H}, J=9.3\right.$ and $\left.4.1 \mathrm{~Hz}, \mathrm{CHHOCH}_{3}\right)$, 3.44 and $3.40\left(\mathrm{AB} \mathrm{q}, 2 \mathrm{H}, J=9.9 \mathrm{~Hz}_{\mathrm{ArCH}}\right), 3.6-3.45[\mathrm{~m}, 1 \mathrm{H}$, $\mathrm{NCH}$ (bridgehead)], $3.30\left(\mathrm{~s}, 3 \mathrm{H}, \mathrm{OCH}_{3}\right), 2.4-2.25(\mathrm{~m}, 1 \mathrm{H}, \mathrm{CHH})$, 2.1-1.6 (m, $5 \mathrm{H}, \mathrm{CH} H$ and $\left.\mathrm{CH}_{2}\right) ;{ }^{13} \mathrm{C}$ NMR $\delta 142.9$ (s, C-10a), 129.7, 129.4, and 118.8 (d, $\mathrm{ArC}$ ), 115.3 (s, C-6a), 114.9 and 113.3 (s, CN), 113.6 (d, Ar C), 69.2 (t, $\left.\mathrm{CH}_{2} \mathrm{OCH}_{3}\right), 59.1\left(\mathrm{q}, \mathrm{OCH}_{3}\right), 56.7$ [d, $\mathrm{NCH}$ (bridgehead)], 52.0 [d, $\mathrm{NCH}\left(\mathrm{CH}_{2} \mathrm{OCH}_{3}\right)$ ], $37.6\left[\mathrm{~s}, \mathrm{C}(\mathrm{CN})_{2}\right.$ ], 37.5 $\left(\mathrm{t}, \mathrm{ArCH}_{2}\right), 29.7,25.3$, and $18.2\left(\mathrm{t}, \mathrm{CH}_{2}\right)$; IR $(\mathrm{KBr}) 2230(\mathrm{CN}) \mathrm{cm}^{-1}$; mass spectrum, $m / e 281.149\left(\mathrm{M}^{+}\right.$, calcd 281.152). Anal. Calcd for $\mathrm{C}_{17} \mathrm{H}_{19} \mathrm{~N}_{3} \mathrm{O}\left(M_{\mathrm{r}} 281.359\right)$ : C, $72.57 ; \mathrm{H}, 6.81 ; \mathrm{N}, 14.92$. Found: $\mathrm{C}, 72.29 ; \mathrm{H}, 6.76 ; \mathrm{N}, 14.71$.

trans $-( \pm)-1,2,3,3 a-T e t r a h y d r o-5-m e t h y l p y r r o l o[1,2-a]$ quinoline-4,4(5H)-dicarbonitrile (5h): $\operatorname{mp~} 130-131{ }^{\circ} \mathrm{C}$ $(\mathrm{MeOH}) ;{ }^{1} \mathrm{H}$ NMR $\delta$ 7.35-7.1 (m, $\left.2 \mathrm{H}, \mathrm{Ar} \mathrm{H}\right), 6.85-6.7(\mathrm{~m}, 1 \mathrm{H}$, Ar H), 6.6-6.5 (m, $1 \mathrm{H}, \mathrm{Ar} \mathrm{H}$ ), 3.88 [dd, $1 \mathrm{H}, J=8.2$ and $5.9 \mathrm{~Hz}$, NCH (bridgehead)], 3.6-3.3 [m, 3 H, NCH, $\left.\mathrm{ArCH}\left(\mathrm{CH}_{3}\right)\right], 2.6-2.45$ and 2.35-1.95 $\left(\mathrm{m}, 4 \mathrm{H}, \mathrm{CH}_{2}\right), 1.75\left[\mathrm{~d}, 3 \mathrm{H}, J=6.8 \mathrm{~Hz}, \mathrm{ArCH}\left(\mathrm{CH}_{3}\right)\right]$; ${ }^{13} \mathrm{C}$ NMR $\delta 142.0(\mathrm{~s}, \mathrm{C}-9 \mathrm{a}), 129.0,126.8,117.5$, and $111.9(\mathrm{~d}, \mathrm{Ar}$ C), $118.7(\mathrm{~s}, \mathrm{C}-5 \mathrm{a}), 115.2(\mathrm{~s}, \mathrm{CN}), 63.0(\mathrm{~d}, \mathrm{NCH}), 48.1\left(\mathrm{t}, \mathrm{NCH}_{2}\right)$, $42.3\left[\mathrm{~s}, \mathrm{C}(\mathrm{CN})_{2}\right], 41.1\left[\mathrm{~d}, \mathrm{ArCH}\left(\mathrm{CH}_{3}\right)\right], 30.3$ and $22.7\left(\mathrm{t}, \mathrm{CH}_{2}\right), 16.1$ $\left(\mathrm{q}, \mathrm{CH}_{3}\right)$; IR (KBr) $2245(\mathrm{CN}) \mathrm{cm}^{-1}$; mass spectrum, $m / e 237.128$ $\left(\mathrm{M}^{+}\right.$, calcd for $\left.\mathrm{C}_{15} \mathrm{H}_{15} \mathrm{~N}_{3} 237.127\right)$. No satisfactory elemental analysis could be obtained.

trans $-( \pm)-1,2,3,3 a-T e t r a h y d r o-3 a, 5-d i m e t h y l p y r r o l o[1,2-$ a ]quinoline-4,4(5H)-dicarbonitrile $(5 \mathrm{i})$ : $\operatorname{mp} 112-113^{\circ} \mathrm{C}$ (MeOH); ${ }^{1} \mathrm{H}$ NMR (200 MHz) $\delta 7.35-7.15(\mathrm{~m}, 2 \mathrm{H}$, Ar H), 6.85-6.7 and 6.65-6.55 (m, 2 H, Ar H), 3.75-3.6 (m, $\left.1 \mathrm{H}, \mathrm{NCH}_{\mathrm{eq}} \mathrm{H}_{\mathrm{az}}\right)$, 3.55-3.35 [m, $\left.2 \mathrm{H}, \mathrm{NCH}_{\mathrm{oq}} H_{\mathrm{ax}}, \mathrm{ArCH}\left(\mathrm{CH}_{3}\right)\right], 2.55-2.1\left(\mathrm{~m}, 4 \mathrm{H}, \mathrm{CH}_{2}\right)$, $1.76\left[\mathrm{~d}, 3 \mathrm{H}, J=6.8 \mathrm{~Hz}, \operatorname{ArCH}\left(\mathrm{CH}_{3}\right)\right], 1.28\left[\mathrm{~s}, 3 \mathrm{H}, \mathrm{NC}\left(\mathrm{CH}_{3}\right)\right]$; ${ }^{13} \mathrm{C}$ NMR $\delta 140.8$ (s, C-9a), 128.9, 127.7, 117.3, and 113.1 (d, Ar C), $118.4(\mathrm{~s}, \mathrm{C}-5 \mathrm{a}), 115.5(\mathrm{~s}, \mathrm{CN}), 64.0\left[\mathrm{~s}, \mathrm{NC}\left(\mathrm{CH}_{3}\right)\right], 47.9\left(\mathrm{t}, \mathrm{NCH}_{2}\right)$, $37.6\left(\mathrm{t}, \mathrm{CH}_{2}\right), 36.6\left[\mathrm{~d}, \operatorname{ArCH}\left(\mathrm{CH}_{3}\right)\right.$ ], $21.5\left(\mathrm{t}, \mathrm{CH}_{2}\right), 21.0[\mathrm{q}, \mathrm{NC}-$ $\left(\mathrm{CH}_{3}\right)$ ], 16.8 [q, $\mathrm{ArCH}\left(\mathrm{CH}_{3}\right)$ ]; IR $(\mathrm{KBr}) 2240(\mathrm{CN}) \mathrm{cm}^{-1}$; mass spectrum, $m / e$ 251.142 (M $\mathbf{M}^{+}$, calcd 251.142). Anal. Calcd for $\mathrm{C}_{16} \mathrm{H}_{17} \mathrm{~N}_{3}\left(M_{\mathrm{r}} 251.332\right)$ : C, 76.46; $\mathrm{H}, 6.82 ; \mathrm{N}, 16.72$. Found: $\mathrm{C}$, $76.13 ; \mathrm{H}, 7.00 ; \mathrm{N}, 16.81$.

trans - $( \pm)-1,2,3,3$ a-Tetrahydro-3a-(methoxymethyl)-5methylpyrrolo[ $1,2-a] q u i n o l i n e-4,4(5 H)$-dicarbonitrile $(5 j)$ : $\mathrm{mp} 139-141{ }^{\circ} \mathrm{C}(\mathrm{MeOH}){ }^{1} \mathrm{H}$ NMR $(200 \mathrm{MHz}) \delta 7.3-7.15(\mathrm{~m}, 2$ $\mathrm{H}, \mathrm{Ar} \mathrm{H}), 6.85-6.75$ and 6.7-6.6 (m, $2 \mathrm{H}, \mathrm{Ar} \mathrm{H}), 3.8-3.65(\mathrm{~m}, 1$ $\mathrm{H}, \mathrm{NCH}_{\mathrm{eq}} \mathrm{H}_{\mathrm{ax}}$, 3.6-3.3 [m, $4 \mathrm{H}, \mathrm{NCH}_{\mathrm{eq}} \mathrm{H}_{\mathrm{ax}}, \mathrm{CH}_{2} \mathrm{OCH}_{3}, \mathrm{ArCH}-$ $\left(\mathrm{CH}_{3}\right)$ ], $3.29\left(\mathrm{~s}, 3 \mathrm{H}, \mathrm{OCH}_{3}\right), 2.7-2.1\left(\mathrm{~m}, 4 \mathrm{H}, \mathrm{CH}_{2}\right), 1.76(\mathrm{~d}, 3 \mathrm{H}$, $\left.J=6.7 \mathrm{~Hz}, \mathrm{CH}_{3}\right) ;{ }^{13} \mathrm{C}$ NMR $\delta 141.7(\mathrm{~s}, \mathrm{C}-9 \mathrm{a}), 128.8,127.1,117.7$, and 113.7 (d, $\mathrm{Ar}$ C), 119.2 (s, C-5a), 114.9 and 113.4 (s, CN), 73.7 $\left(\mathrm{t}, \mathrm{CH}_{2} \mathrm{OCH}_{3}\right), 66.2\left[\mathrm{~s}, \mathrm{NC}\left(\mathrm{CH}_{2} \mathrm{OCH}_{3}\right)\right], 59.6\left(\mathrm{q}, \mathrm{OCH}_{3}\right), 49.0(\mathrm{t}$, $\left.\mathrm{NCH}_{2}\right), 45.5\left[\mathrm{~s}, \mathrm{C}(\mathrm{CN})_{2}\right], 36.4\left(\mathrm{~d}, \mathrm{ArCH}\left(\mathrm{CH}_{3}\right)\right], 34.1$ and $22.1(\mathrm{t}$, $\left.\mathrm{CH}_{2}\right), 16.8\left(\mathrm{q}, \mathrm{CH}_{3}\right) ; \mathrm{IR}(\mathrm{KBr}) 2260(\mathrm{CN}) \mathrm{cm}^{-1}$; mass spectrum, $m / e$ 281.152 $\left(\mathrm{M}^{+}\right.$, calcd 281.153). Anal. Calcd for $\mathrm{C}_{17} \mathrm{H}_{19} \mathrm{~N}_{3} \mathrm{O}\left(M_{\mathrm{r}}\right.$ 281.358): C, 72.57; H, 6.81; N, 14.93. Found: C, 72.92; H, 6.94; $\mathrm{N}, 15.19$

(1 $\alpha, 3 \mathrm{a} \alpha, 5 \beta)-1,2,3,3 \mathrm{a}-$ Tetrahydro-1 -(methoxymethyl)-5methylpyrrolo $[1,2-\Omega]$ quinoline-4,4(5H)-dicarbonitrile $(6 \mathrm{j})$ : $\mathrm{mp} 123-125{ }^{\circ} \mathrm{C}(\mathrm{MeOH}) ;{ }^{1} \mathrm{H}$ NMR $(200 \mathrm{MHz}) \delta 7.25-7.1$ and 6.85-6.65 (m, 4 H, Ar H) , 4.2-4.1 (m, $\left.1 \mathrm{H}, \mathrm{NCH}\left(\mathrm{CH}_{2} \mathrm{OCH}_{3}\right)\right], 4.01$ [dd, $1 \mathrm{H}, J=8.1$ and $4.0 \mathrm{~Hz}, \mathrm{NCH}$ (bridgehead)], 3.53 (ABX, 1 $\mathrm{H}, J=12.5$ and $\left.5.4 \mathrm{~Hz}, \mathrm{CH} \mathrm{HOCH}_{3}\right), 3.48(\mathrm{ABX}, 1 \mathrm{H}, J=12.5$ and $\left.3.7 \mathrm{~Hz}, \mathrm{CH} H \mathrm{OCH}_{3}\right), 3.44\left[\mathrm{q}, 1 \mathrm{H}, J=6.8 \mathrm{~Hz}, \operatorname{ArCH}\left(\mathrm{CH}_{3}\right)\right]$, $3.34\left(\mathrm{~s}, 3 \mathrm{H}, \mathrm{OCH}_{3}\right), 2.65-2.5(\mathrm{~m}, 1 \mathrm{H}, \mathrm{CHH}), 2.4-2.2\left(\mathrm{~m}, 2 \mathrm{H}, \mathrm{CH}_{2}\right)$, $2.1-1.9(\mathrm{~m}, 1 \mathrm{H}, \mathrm{CH}), 1.73\left[\mathrm{~d}, 3 \mathrm{H}, J=6.8 \mathrm{~Hz}, \operatorname{ArCH}\left(\mathrm{CH}_{3}\right)\right]$ ${ }^{13} \mathrm{C}$ NMR $\delta 141.2$ (s, C-9a), 128.6, 126.9, 117.7, and 112.1 (d, Ar C), $118.6(\mathrm{~s}, \mathrm{C}-5 \mathrm{a}), 115.5$ and $112.3(\mathrm{~s}, \mathrm{CN}), 73.4\left(\mathrm{t}, \mathrm{CH}_{2} \mathrm{OCH}_{3}\right)$, 62.7 [d, NCH (bridgehead)], 60.5 [d, $\mathrm{NCH}\left(\mathrm{CH}_{2} \mathrm{OCH}_{3}\right)$ ], 59.3 (q, $\left.\mathrm{OCH}_{3}\right), 42.1\left[\mathrm{~s}, \mathrm{C}(\mathrm{CN})_{2}\right], 40.8$ [d, $\left.\mathrm{ArCH}\left(\mathrm{CH}_{3}\right)\right], 28.8$ and 26.0 ( $\mathrm{t}$, $\left.\mathrm{CH}_{2}\right), 15.9\left(\mathrm{q}, \mathrm{CH}_{3}\right)$; IR $(\mathrm{KBr}) 2240(\mathrm{CN}) \mathrm{cm}^{-1}$; mass spectrum, $m / e$ 281.152 $\left(\mathrm{M}^{+}\right.$, calcd 281.153). Anal. Calcd for $\mathrm{C}_{17} \mathrm{H}_{19} \mathrm{~N}_{3} \mathrm{O}\left(M_{\mathrm{r}}\right.$ 281.358): C, 72.57; H, 6.81; N, 14.93. Found: C, 72.21; H, 6.92; $\mathrm{N}, 15.00$.

(1a $\alpha, 3 a \beta, 5 \alpha)-1,2,3,3 a-T e t r a h y d r o-1-(m e t h o x y m e t h y l)-5-$ methylpyrrolo[1,2-a ]quinoline-4,4(5H)-dicarbonitrile $(7 \mathbf{j})$ : mp $139-141{ }^{\circ} \mathrm{C}(\mathrm{MeOH}) ;{ }^{1} \mathrm{H}$ NMR $(200 \mathrm{MHz}) \delta 7.25-7.15$ and 6.8-6.1 (m, 4 H, Ar H), 4.2-4.05 [m, $\left.1 \mathrm{H}, \mathrm{NCH}\left(\mathrm{CH}_{2} \mathrm{OCH}_{3}\right)\right], 3.83$ [dd, $1 \mathrm{H}, J=9.2$ and $4.5 \mathrm{~Hz}, \mathrm{NCH}$ (bridgehead)], 3.57 (dd, $1 \mathrm{H}$, $J=9.3$ and $2.7 \mathrm{~Hz}, \mathrm{CHHOCH}_{3}$ ), $3.50[\mathrm{q}, 1 \mathrm{H}, J=6.9 \mathrm{~Hz}$, $\left.\operatorname{ArCH}\left(\mathrm{CH}_{3}\right)\right], 3.36\left(\mathrm{~s}, 3 \mathrm{H}, \mathrm{OCH}_{3}\right), 3.15(\mathrm{dd}, 1 \mathrm{H}, J=9.3$ and 9.3 $\left.\mathrm{Hz}, \mathrm{CH} H \mathrm{OCH}_{3}\right), 2.5-2.35(\mathrm{~m}, 1 \mathrm{H}, \mathrm{CHH}), 2.3-2.0(\mathrm{~m}, 3 \mathrm{H}, \mathrm{CH} H$ and $\left.\mathrm{CH}_{2}\right), 1.74\left[\mathrm{~d}, 3 \mathrm{H}, J=6.9 \mathrm{~Hz}, \mathrm{ArCH}\left(\mathrm{CH}_{3}\right)\right.$ ]; ${ }^{13} \mathrm{C}$ NMR $\delta 140.8$ 
(s, C-9a), 129.3, 128.9, 117.9, and 112.2 (d, Ar C), 119.9 (s, C-5a), 114.8 and $113.1(\mathrm{~s}, \mathrm{CN}), 71.8\left(\mathrm{t}, \mathrm{CH}_{2} \mathrm{OCH}_{3}\right), 63.1$ (d, $\mathrm{NCH}$ (bridgehead)], 59.1 (q, $\mathrm{OCH}_{3}$ ), 56.9 [d, $\mathrm{NCH}\left(\mathrm{CH}_{2} \mathrm{OCH}_{3}\right)$ ], 43.8 [s, $\mathrm{C}(\mathrm{CN})_{2}$ ] $42.6\left[\mathrm{~d}, \mathrm{ArCH}\left(\mathrm{CH}_{3}\right)\right], 28.0$ and $27.2\left(\mathrm{t}, \mathrm{CH}_{2}\right), 16.9(\mathrm{q}$, $\left.\mathrm{CH}_{3}\right)$; IR (KBr) $2240(\mathrm{CN}) \mathrm{cm}^{-1}$; mass spectrum, $m / e 281.151\left(\mathrm{M}^{+}\right.$ calcd 281.153). Anal. Calcd for $\mathrm{C}_{17} \mathrm{H}_{19} \mathrm{~N}_{3} \mathrm{O}\left(M_{\mathrm{r}} 281.358\right)$ : C, 72.57; $\mathrm{H}, 6.81 ; \mathrm{N}, 14.93$. Found: C, 72.32; H, 6.77; N, 14.63 .

trans $-( \pm)-2,3,4,4 a-T e t r a h y d r o-6$-methyl- $1 H$-benzo[c]quinolizine-5,5(6H)-dicarbonitrile (5k): $\mathrm{mp} 145.5-146.5^{\circ} \mathrm{C}$ $(\mathrm{MeOH}) ;{ }^{1} \mathrm{H}$ NMR $(200 \mathrm{MHz}) \delta 7.25-7.1$ and $6.95-6.8(\mathrm{~m}, 4 \mathrm{H}$, Ar H), 3.99 (br d, $1 \mathrm{H}, J=11.3 \mathrm{~Hz}, \mathrm{NCH}_{\mathrm{eq}} \mathrm{H}_{\mathrm{ax}}$ ), 3.52 [q, $1 \mathrm{H}, J$ $\left.=6.9 \mathrm{~Hz}, \operatorname{ArCH}\left(\mathrm{CH}_{3}\right)\right], 3.33[\mathrm{dd}, 1 \mathrm{H}, J=11.3$ and $3.2 \mathrm{~Hz}, \mathrm{NCH}$ (bridgehead)], 2.68 [ddd, $1 \mathrm{H}, J=11.3,11.3$, and $3.4 \mathrm{~Hz}$, $\left.\mathrm{NCH}_{\text {eq }} \mathrm{H}_{\mathrm{ax}}\right], 2.45-2.3(\mathrm{~m}, 1 \mathrm{H}, \mathrm{CHH}), 2.1-1.4(\mathrm{~m}, 5 \mathrm{H}, \mathrm{CH} H$ and $\left.\mathrm{CH}_{2}\right), 1.75\left[\mathrm{~d}, 3 \mathrm{H}, J=6.9 \mathrm{~Hz}, \operatorname{ArCH}\left(\mathrm{CH}_{3}\right)\right] ;{ }^{13} \mathrm{C} \mathrm{NMR} \delta 144.6$ (s, C-10a), 128.8 and 126.9 (d, Ar C), 121.3 (s, C-6a), 119.5 and 113.9 (d, Ar C), 115.0 and 112.3 (s, CN), $60.1(\mathrm{~d}, \mathrm{NCH}), 48.1(\mathrm{t}$, $\left.\mathrm{NCH}_{2}\right), 46.2\left[\mathrm{~s}, \mathrm{C}(\mathrm{CN})_{2}\right], 39.9\left[\mathrm{~d}, \operatorname{ArCH}\left(\mathrm{CH}_{3}\right)\right], 30.0,24.8$, and 22.7 (t, $\left.\mathrm{CH}_{2}\right), 16.6\left(\mathrm{q}, \mathrm{CH}_{3}\right)$; IR $(\mathrm{KBr}) 2260(\mathrm{CN}) \mathrm{cm}^{-1}$; mass spectrum, $m / e$ 251.143 ( $\mathrm{M}^{+}$, calcd 251.142). Anal. Calcd for $\mathrm{C}_{16} \mathrm{H}_{17} \mathrm{~N}_{3}\left(M_{\mathrm{r}}\right.$ 251.332): C, $76.40 ; \mathrm{H}, 6.84 ; \mathrm{N}, 16.86$. Found: C, $76.46 ; \mathrm{H}, 6.82$; $\mathrm{N}, 16.72$.

trans -( \pm )-2,3,4,4a-Tetrahydro-4a,6-dimethyl-1 $H$-benzo[c]quinolizine-5,5(6H)-dicarbonitrile (5l): $\mathrm{mp} 146-148^{\circ} \mathrm{C}$ $(\mathrm{MeOH}) ;{ }^{1} \mathrm{H}$ NMR $(200 \mathrm{MHz}) \delta 7.3-6.7(\mathrm{~m}, 4 \mathrm{H}, \mathrm{Ar} \mathrm{H}), 3.69(\mathrm{br}$ d, $\left.1 \mathrm{H}, J=11.9 \mathrm{~Hz}, \mathrm{NCH}_{\mathrm{eq}} \mathrm{H}_{\mathrm{ax}}\right), 3.46[\mathrm{q}, 1 \mathrm{H}, J=6.6 \mathrm{~Hz}$ $\operatorname{ArCH}\left(\mathrm{CH}_{3}\right)$ ], 2.65 [ddd, $1 \mathrm{H}, J=11.9,11.9$, and $3.5 \mathrm{~Hz}$ $\left.\mathrm{NCH}_{\mathrm{eg}} H_{\mathrm{ax}}\right), 2.2-1.5\left(\mathrm{~m}, 6 \mathrm{H}, \mathrm{CH}_{2}\right), 1.76[\mathrm{~d}, 3 \mathrm{H}, J=6.6 \mathrm{~Hz}$ $\left.\operatorname{ArCH}\left(\mathrm{CH}_{3}\right)\right], 1.21\left[\mathrm{~s}, 3 \mathrm{H}, \mathrm{NC}\left(\mathrm{CH}_{3}\right)\right] ;{ }^{13} \mathrm{C} \mathrm{NMR} \delta 143.5$ (s, C-10a), 128.8 and 127.2 (d, Ar C), 121.0 (s, C-6a), 119.1 (d, Ar C), 115.2 and $113.5(\mathrm{~s}, \mathrm{CN}), 113.3(\mathrm{~d}, \mathrm{Ar} \mathrm{C}), 57.8\left[\mathrm{~s}, \mathrm{NC}\left(\mathrm{CH}_{3}\right)\right], 51.8[\mathrm{~s}$ $\mathrm{C}(\mathrm{CN})_{2}$ ], $42.8\left(\mathrm{t}, \mathrm{NCH}_{2}\right), 36.0$ [d, $\left.\mathrm{ArCH}\left(\mathrm{CH}_{3}\right)\right], 35.7,24.9$, and 19.2 $\left(\mathrm{t}, \mathrm{CH}_{2}\right), 17.3$ and $14.1\left(\mathrm{q}, \mathrm{CH}_{3}\right)$; IR $(\mathrm{KBr}) 2240(\mathrm{CN}) \mathrm{cm}^{-1}$; mass spectrum, $m / e$ 265.156 ( $\mathrm{M}^{+}$, calcd 265.158). Anal. Calcd for $\mathrm{C}_{17} \mathrm{H}_{19} \mathrm{~N}_{3}\left(M_{\mathrm{r}} 265.359\right)$ : C, $76.95 ; \mathrm{H}, 7.22 ; \mathrm{N}, 15.83$. Found: $\mathrm{C}$, $76.66 ; \mathrm{H}, 7.34 ; \mathrm{N}, 15.95$.

trans - ( \pm )-2,3,4,4a-Tetrahydro-4a-ethyl-6-methyl-1 $H$. benzo[c]quinolizine-5,5(6H)-dicarbonitrile $(5 \mathrm{~m})$ : $\mathrm{mp}$ $113.5-114.5^{\circ} \mathrm{C}(\mathrm{MeOH}) ;{ }^{1} \mathrm{H}$ NMR $(200 \mathrm{MHz}) \delta 7.3-7.1$ and $6.9-6.7$ $(\mathrm{m}, 4 \mathrm{H}, \mathrm{Ar} \mathrm{H}), 3.64\left(\mathrm{br} \mathrm{d}, 1 \mathrm{H}, J=11.8 \mathrm{~Hz}, \mathrm{NCH}_{\mathrm{eq}} \mathrm{H}_{\mathrm{az}}\right), 3.46([\mathrm{q}$ $1 \mathrm{H}, J=7.0 \mathrm{~Hz}, \mathrm{ArCH}\left(\mathrm{CH}_{3}\right)$ ], 2.82 (ddd, $1 \mathrm{H}, J=11.8,11.8$, and $\left.3.6 \mathrm{~Hz}, \mathrm{NCH}_{\mathrm{eq}} H_{\mathrm{ax}}\right), 2.6-2.4(\mathrm{~m}, 1 \mathrm{H}, \mathrm{CHH}), 2.15-1.5(\mathrm{~m}, 7 \mathrm{H}, \mathrm{CH}$, $\left.\mathrm{CH}_{2}, \mathrm{CH}_{2} \mathrm{CH}_{3}\right), 1.77\left[\mathrm{~d}, 3 \mathrm{H}, J=7.0 \mathrm{~Hz}, \operatorname{ArCH}\left(\mathrm{CH}_{3}\right)\right], 1.00(\mathrm{t}$ $\left.3 \mathrm{H}, J=7.5 \mathrm{~Hz}, \mathrm{CH}_{2} \mathrm{CH}_{3}\right) ;{ }^{13} \mathrm{C}$ NMR $\delta 143.7$ (s, C-10a), 128.7 and 128.6 (d, Ar C), 121.2 (s, C-6a), 118.8 (d, Ar C), 115.5 and 114.2 $(\mathrm{s}, \mathrm{CN}), 113.1(\mathrm{~d}, \mathrm{Ar} \mathrm{C}), 59.8\left[\mathrm{~s}, \mathrm{NC}\left(\mathrm{C}_{2} \mathrm{H}_{5}\right)\right], 51.1\left[\mathrm{~s}, \mathrm{C}(\mathrm{CN})_{2}\right], 43.5$ $\left(\mathrm{t}, \mathrm{NCH}_{2}\right), 36.0$ [d, $\left.\mathrm{ArCH}\left(\mathrm{CH}_{3}\right)\right], 32.2,24.5,23.2$, and $19.5\left(\mathrm{t}, \mathrm{CH}_{2}\right)$, 17.4 [q, $\left.\operatorname{ArCH}\left(\mathrm{CH}_{3}\right)\right], 9.2\left(\mathrm{q}, \mathrm{CH}_{2} \mathrm{CH}_{3}\right) ; \mathrm{IR}(\mathrm{KBr}) 2245(\mathrm{CN}) \mathrm{cm}^{-1}$; mass spectrum, $m / e$ 279.170 ( ${ }^{+}$, calcd 279.173). Anal. Calcd for $\mathrm{C}_{18} \mathrm{H}_{21} \mathrm{~N}_{3}\left(M_{\mathrm{r}} 279.386\right)$ : C, 77.38; $\mathrm{H}, 15.04 ; \mathrm{N}, 7.58$. Found: C, 77.44; H, 15.12; N, 7.59.

trans $-( \pm)-2,3,4,4 a-T e t r a h y d r o-4 a-(m e t h o x y m e t h y l)-6$ methyl-1H-benzo[c]quinolizine-5,5(6H)-dicarbonitrile $(5 n)$ : mp $153-155^{\circ} \mathrm{C}(\mathrm{MeOH}) ;{ }^{1} \mathrm{H}$ NMR $(200 \mathrm{MHz}) \delta 7.3-7.15$ and 6.9-6.75 (m, $4 \mathrm{H}, \mathrm{Ar} \mathrm{H}), 3.75-3.5\left(\mathrm{~m}, 1 \mathrm{H}, \mathrm{NCH}_{\mathrm{eq}} \mathrm{H}_{\mathrm{ax}}\right), 3.62$ and $3.37\left(\mathrm{AB} \mathrm{q}, 2 \mathrm{H}, J=10.3 \mathrm{~Hz}, \mathrm{CH}_{2} \mathrm{OCH}_{3}\right), 3.47[\mathrm{q}, 1 \mathrm{H}, J=6.7$ $\left.\mathrm{Hz}, \mathrm{ArCH}\left(\mathrm{CH}_{3}\right)\right], 3.29\left(\mathrm{~s}, 3 \mathrm{H}, \mathrm{OCH}_{3}\right), 2.85-2.6\left(\mathrm{~m}, 3 \mathrm{H}, \mathrm{NCH}_{\mathrm{eq}} H_{\mathrm{ax}}\right.$, $\left.\mathrm{CH}_{2}\right), 2.1-1.5\left(\mathrm{~m}, 4 \mathrm{H}, \mathrm{CH}_{2}\right), 1.79\left[\mathrm{~d}, 3 \mathrm{H}, J=6.7 \mathrm{~Hz}, \operatorname{ArCH}\left(\mathrm{CH}_{3}\right)\right]$; ${ }^{13} \mathrm{C}$ NMR $\delta 143.5(\mathrm{~s}, \mathrm{C}-10 \mathrm{a}), 128.6$ and $127.2(\mathrm{~d}, \mathrm{Ar} \mathrm{C}), 121.5(\mathrm{~s}$, $\mathrm{C}-6 \mathrm{a}), 118.9$ (d, Ar C), 114.6 and 114.1 (s, CN), 112.7 (d, Ar C), $68.5\left(\mathrm{t}, \mathrm{CH}_{2} \mathrm{OCH}_{3}\right), 59.4\left(\mathrm{q}, \mathrm{OCH}_{3}\right), 59.3\left[\mathrm{~s}, \mathrm{NC}\left(\mathrm{CH}_{2} \mathrm{OCH}_{3}\right)\right], 49.6$ [s, $\left.C(\mathrm{CN})_{2}\right], 43.4\left(\mathrm{t}, \mathrm{NCH}_{2}\right), 35.7\left[\mathrm{~d}, \mathrm{ArCH}\left(\mathrm{CH}_{3}\right)\right], 30.8,24.4$, and $19.0\left(\mathrm{t}, \mathrm{CH}_{2}\right), 17.1\left(\mathrm{q}, \mathrm{CH}_{3}\right)$; IR $(\mathrm{KBr}) 2260(\mathrm{CN}) \mathrm{cm}^{-1}$; mass spectrum, $m / e$ 295.171 ( $\mathrm{M}^{+}$, calcd 295.169). Anal. Calcd for $\mathrm{C}_{18} \mathrm{H}_{21} \mathrm{~N}_{3} \mathrm{O}\left(M_{\mathrm{r}} 295.385\right)$ : C, $73.19 ; \mathrm{H}, 7.17 ; \mathrm{N}, 14.22$. Found: C, $72.99 ; \mathrm{H}, 7.08 ; \mathrm{N}, 13.98$.

$(1 \alpha, 4 \mathrm{a} \alpha, 5 \beta)-( \pm)-2,3,4,4 \mathrm{a}-T e t r a h y d r o-1$-(methoxymethyl)-6methyl-1H-benzo[c]quinolizine-5,5(6H)-dicarbonitrile $(6 n)$ mp $135-136{ }^{\circ} \mathrm{C}(\mathrm{MeOH}) ;{ }^{1} \mathrm{H}$ NMR $(200 \mathrm{MHz}) \delta 7.3-7.1$ and 7.0-6.75 (m, $4 \mathrm{H}, \mathrm{Ar} \mathrm{H}) ; 4.4-4.25\left[\mathrm{~m}, 1 \mathrm{H}, \mathrm{NCH}\left(\mathrm{CH}_{2} \mathrm{OCH}_{3}\right)\right]$, $3.7-3.6[\mathrm{~m}, 1 \mathrm{H}, \mathrm{NCH}$ (bridgehead)], 3.53 (ABX, $1 \mathrm{H}, J=9.0$ and $\left.9.0 \mathrm{~Hz}, \mathrm{C} H \mathrm{HOCH}_{3}\right), 3.34(\mathrm{ABX}, 1 \mathrm{H}, J=9.0$ and $4.0 \mathrm{~Hz}$, $\left.\mathrm{CHHOCH}_{3}\right), 3.43\left[\mathrm{q}, 1 \mathrm{H}, J=6.8 \mathrm{~Hz}, \mathrm{ArCH}\left(\mathrm{CH}_{3}\right)\right], 3.28(\mathrm{~s}, 3 \mathrm{H}$, $\left.\mathrm{OCH}_{3}\right), 2.45-2.3$ and $2.15-2.0\left(\mathrm{~m}, 2 \mathrm{H}, \mathrm{CH}_{2}\right), 1.9-1.7\left(\mathrm{~m}, 4 \mathrm{H}, \mathrm{CH}_{2}\right)$ $1.73\left[\mathrm{~d}, 3 \mathrm{H}, J=6.8 \mathrm{~Hz}, 3 \mathrm{H}, \mathrm{ArCH}\left(\mathrm{CH}_{3}\right)\right] ;{ }^{13} \mathrm{C}$ NMR $\delta 143.0(\mathrm{~s}$ C-10a), 129.1 and 126.9 (d, Ar C), 120.9 (s, C-6a), 118.8 and 113.5 (d, $\mathrm{Ar} \mathrm{C}), 115.0$ and $112.0(\mathrm{~s}, \mathrm{CN}), 68.9\left(\mathrm{t}, \mathrm{CH}_{2} \mathrm{OCH}_{3}\right), 59.0$ (q, $\left.\mathrm{OCH}_{3}\right), 57.2(\mathrm{~d}, \mathrm{NCH}), 52.0$ [d, $\left.\mathrm{NCH}\left(\mathrm{CH}_{2} \mathrm{OCH}_{3}\right)\right], 46.2\left[\mathrm{~s}, \mathrm{C}(\mathrm{CN})_{2}\right.$, $39.8\left[\mathrm{~d}, \mathrm{ArCH}\left(\mathrm{CH}_{3}\right)\right], 30.1,25.3$, and $18.2\left(\mathrm{t}, \mathrm{CH}_{2}\right), 16.1$ (q, $\left.\mathrm{CH}_{3}\right)$; IR (KBr) $2250(\mathrm{CN}) \mathrm{cm}^{-1}$; mass spectrum, $m / e 295.166\left(\mathrm{M}^{+}\right.$, calcd 295.168). Anal. Calcd for $\mathrm{C}_{18} \mathrm{H}_{21} \mathrm{~N}_{3} \mathrm{O}\left(M_{\mathrm{r}} 295.385\right)$ : C, $73.19 ; \mathrm{H}$, $7.17 ; \mathrm{N}, 14.22$. Found: C, 73.03; H, 7.30; N, 14.29.

trans $-( \pm)$ - and cis $-( \pm)-1,2,3,3 \mathrm{a}-$ tetrahydro-5-(4-methylphenyl) pyrrolo[1,2-a ]quinoline-4,4(5H)-dicarbonitrile (5o

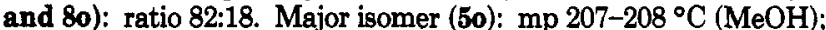
${ }^{1} \mathrm{H}$ NMR $(200 \mathrm{MHz}) \delta 7.4-7.15(\mathrm{~m}, 5 \mathrm{H}, \mathrm{Ar} \mathrm{H}), 6.8-6.6(\mathrm{~m}, 3 \mathrm{H}$, $\operatorname{Ar~H}), 4.55\left[\mathrm{~s}, 1 \mathrm{H}, \operatorname{ArCH}\left(\mathrm{C}_{6} \mathrm{H}_{4} \mathrm{CH}_{3}\right)\right], 4.03$ [dd, $1 \mathrm{H}, J=7.8$ and $6.3 \mathrm{~Hz}, \mathrm{NCH}$ (bridgehead) $, 3.65-3.4\left(\mathrm{~m}, 2 \mathrm{H}, \mathrm{NCH}_{2}\right), 2.39(\mathrm{~s}, 3$ $\left.\mathrm{H}, \mathrm{CH}_{3}\right), 2.60-2.0\left(\mathrm{~m}, 4 \mathrm{H}, \mathrm{CH}_{2}\right.$ ); ${ }^{13} \mathrm{C}$ NMR $\delta 142.7$ (s, C-9a), 138.9 and 133.1 (s, Ar C), 129.5 and $129.2(\mathrm{~d}, \operatorname{Ar} \mathrm{C}), 118.3(\mathrm{~s}, \mathrm{C}-5 \mathrm{a}), 117.2$ (d, $\mathrm{Ar} \mathrm{C}$ ), 114.5 and 112.6 (s, CN), 112.1 (d, Ar C), 63.5 [d, CH$\left.\left(\mathrm{C}_{6} \mathrm{H}_{4} \mathrm{CH}_{3}\right)\right], 53.1(\mathrm{~d}, \mathrm{NCH}), 47.9\left(\mathrm{t}, \mathrm{NCH}_{2}\right), 43.3$ [s, $\left.\mathrm{C}(\mathrm{CN})_{2}\right], 30.1$ and $22.6\left(\mathrm{t}, \mathrm{CH}_{2}\right), 21.2\left(\mathrm{q}, \mathrm{CH}_{3}\right)$; IR $(\mathrm{KBr}) 2260(\mathrm{CN}) \mathrm{cm}^{-1}$; mass spectrum, $m / e 313.153\left(\mathrm{M}^{+}\right.$, calcd 313.157$)$. Anal. Calcd for $\mathrm{C}_{21} \mathrm{H}_{19} \mathrm{~N}_{3}\left(M_{\mathrm{r}} 313.403\right)$ : C, 80.49; $\mathrm{H}, 6.11 ; \mathrm{N}, 13.41$. Found: C, 80.39; H, 6.11; N, 13.42 .

trans -( \pm - and cis $-( \pm)-1,2,3,3 a-t e t r a h y d r o-3 a-m e t h y l-5-$ (4-methylphenyl)pyrrolo $[1,2-a]$ quinoline-4,4(5H)-dicarbonitrile (5p and 8p): ratio 98:2. Major isomer (5p): $m p$ 184-186 ${ }^{\circ} \mathrm{C}(\mathrm{MeOH}):{ }^{1} \mathrm{H}$ NMR $(200 \mathrm{MHz}) \delta 7.5-7.1(\mathrm{~m}, 5 \mathrm{H}, \mathrm{Ar} \mathrm{H})$, 6.95-6.5 (m, $3 \mathrm{H}, \mathrm{Ar} \mathrm{H}), 4.52$ [s, $1 \mathrm{H}, \mathrm{ArCH}\left(\mathrm{C}_{6} \mathrm{H}_{4} \mathrm{CH}_{3}\right)$ ], 3.8-3.4 $\left(\mathrm{m}, 2 \mathrm{H}, \mathrm{NCH}_{2}\right), 2.6-2.1\left(\mathrm{~m}, 4 \mathrm{H}, \mathrm{CH}_{2}\right), 2.38\left(\mathrm{~s}, 3 \mathrm{H}, \mathrm{ArCH}_{3}\right), 1.39$ [s, $3 \mathrm{H}, \mathrm{CH}_{3}$ (bridgehead)]; ${ }^{13} \mathrm{C}$ NMR $\delta 141.7(\mathrm{~s}, \mathrm{C}-9 \mathrm{a}), 138.8$ and 133.7 (s, Ar C), 129.9, 129.4, and 129.0 (d, Ar C), 117.5 (s, C-5a), 117.0 (d, $\mathrm{Ar} \mathrm{C}), 114.9$ and $113.7\left[\mathrm{~s}, C(\mathrm{CN})_{2}\right], 113.2(\mathrm{~d}, \mathrm{Ar} \mathrm{C}), 64.9$ $\left[\mathrm{s}, \mathrm{NC}\left(\mathrm{CH}_{3}\right)\right], 48.9\left[\mathrm{~d}, \mathrm{ArCH}\left(\mathrm{C}_{6} \mathrm{H}_{4} \mathrm{CH}_{3}\right)\right], 47.7\left(\mathrm{t}, \mathrm{NCH}_{2}\right), 37.6$ and $21.5\left(\mathrm{t}, \mathrm{CH}_{2}\right), 21.2$ and $20.8\left(\mathrm{q}, \mathrm{CH}_{3}\right) ; \mathrm{IR}(\mathrm{KBr}) 2255(\mathrm{CN}) \mathrm{cm}^{-1}$; mass spectrum, $m / e 327.168\left(\mathrm{M}^{+}\right.$, calcd 327.173$)$. Anal. Calcd for $\mathrm{C}_{22} \mathrm{H}_{21} \mathrm{~N}_{3}\left(M_{z} 327.413\right): \mathrm{C}, 80.70 ; \mathrm{H}, 6.46 ; \mathrm{N}, 12.83$. Found: $\mathrm{C}, 80.34 ; \mathrm{H}, 6.39 ; \mathrm{N}, 12.71$.

trans $-( \pm)$ - and cis - $( \pm)-1,2,3,3 \mathrm{a}-$ tetrahydro-3a-(methoxymethyl)-5-(4-methylphenyl) pyrrolo[1,2-a ]quinoline-4,4(5H)-dicarbonitrile (5q and $\mathbf{8 q}$ ): ratio $95: 5$. Major isomer (5q): $\mathrm{mp} 222-223^{\circ} \mathrm{C}(\mathrm{MeOH}) ;{ }^{1} \mathrm{H}$ NMR $(200 \mathrm{MHz}) \delta 7.4-7.2(\mathrm{~m}, 5 \mathrm{H}$, Ar H), 6.85-6.6 (m, 3 H, Ar H), 4.56 [s, $1 \mathrm{H}, \operatorname{ArCH}\left(\mathrm{C}_{6} \mathrm{H}_{4} \mathrm{CH}_{3}\right)$ ], 3.85-3.7 (m, $\left.1 \mathrm{H}, \mathrm{NCH}_{\mathrm{eq}} \mathrm{H}_{\mathrm{az}}\right), 3.61$ and $3.46(\mathrm{AB} \mathrm{q}, 2 \mathrm{H}, J=10.1$ $\left.\mathrm{Hz}, \mathrm{CH}_{2} \mathrm{OCH}_{3}\right), 3.6-3.4\left(\mathrm{~m}, 1 \mathrm{H}, \mathrm{NCH}_{\mathrm{eq}} H_{\mathrm{ar}}\right), 3.36$ (s, $\left.3 \mathrm{H}, \mathrm{OCH}_{3}\right)$, $2.65-2.15\left(\mathrm{~m}, 4 \mathrm{H}, \mathrm{CH}_{2}\right), 2.39\left(\mathrm{~s}, 3 \mathrm{H}, \mathrm{CH}_{3}\right) ;{ }^{13} \mathrm{C} \mathrm{NMR} \delta 142.0(\mathrm{~s}$, C-9a), 138.9 and 133.7 (s, Ar C), 129.9, 129.4, and 129.0 (d, Ar C), $118.3(\mathrm{~s}, \mathrm{C}-5 \mathrm{a}), 117.3(\mathrm{~d}, \mathrm{Ar}$ C), 114.3 and $114.0(\mathrm{~s}, \mathrm{CN}), 113.8(\mathrm{~d}$, Ar C), $73.7\left(\mathrm{t}, \mathrm{CH}_{2} \mathrm{OCH}_{3}\right), 67.1$ [s, $\left.\mathrm{NC}\left(\mathrm{CH}_{2} \mathrm{OCH}_{3}\right)\right], 59.7$ (q, $\left.\mathrm{CH}_{2} \mathrm{OCH}_{3}\right)$ ], $48.8\left(\mathrm{t}, \mathrm{NCH}_{2}\right), 48.7\left[\mathrm{~d}, \mathrm{ArCH}\left(\mathrm{C}_{6} \mathrm{H}_{4} \mathrm{CH}_{3}\right)\right.$ ], 46.3 [s, $\left.C(\mathrm{CN})_{2}\right], 34.2$ and $22.3\left(t, \mathrm{CH}_{2}\right), 21.2\left(\mathrm{q}, \mathrm{C}_{6} \mathrm{H}_{4} \mathrm{CH}_{3}\right) ; \mathrm{IR}(\mathrm{KBr}) 2260$ (CN) $\mathrm{cm}^{-1}$; mass spectrum, $m / e 357.186\left(\mathrm{M}^{+}\right.$, calcd 357.184). Anal. Calcd for $\mathrm{C}_{23} \mathrm{H}_{23} \mathrm{~N}_{3} \mathrm{O}\left(M_{\mathrm{r}} 357.456\right)$ : C, 77.28; $\mathrm{H}, 6.49 ; \mathrm{N}, 11.75$. Found: C, $77.01 ; \mathrm{H}, 6.53 ; \mathrm{N}, 11.71$

$(1 \alpha, 3 \mathrm{a} \alpha, 5 \beta)-( \pm)-$ and $(1 \alpha, 3 \mathrm{a} \alpha, 5 \alpha)-( \pm)-1,2,3,3 \mathrm{a}-$ tetrahydro1-(methoxymethyl)-5-(4-methylphenyl) pyrrolo[1,2-a ] quinoline-4,4(5H)-dicarbonitrile (6q and 9q): ratio 96:4. Major isomer $(6 q): \operatorname{mp~} 192-193{ }^{\circ} \mathrm{C}(\mathrm{MeOH}) ;{ }^{1} \mathrm{H}$ NMR $(200 \mathrm{MHz}) \delta$ 7.4-7.15 (m, $5 \mathrm{H}, \mathrm{Ar} \mathrm{H}), 6.8-6.6(\mathrm{~m}, 3 \mathrm{H}, \mathrm{Ar} \mathrm{H}), 4.54$ [s, $1 \mathrm{H}$ $\left.\operatorname{ArCH}\left(\mathrm{C}_{6} \mathrm{H}_{4} \mathrm{CH}_{3}\right)\right], 4.3-4.15\left[\mathrm{~m}, 1 \mathrm{H}, \mathrm{NCH}\left(\mathrm{CH}_{2} \mathrm{OCH}_{3}\right)\right], 4.19[\mathrm{dd}$ $1 \mathrm{H}, J=3.6$ and $8.3 \mathrm{~Hz}, \mathrm{NCH}$ (bridgehead) ], 3.58 (ABX, $1 \mathrm{H}$, $J=9.5$ and $5.5 \mathrm{~Hz}, \mathrm{CHHOCH}), 3.52(\mathrm{ABX}, 1 \mathrm{H}, J=9.5$ and $\left.3.8 \mathrm{~Hz}, \mathrm{CH} \mathrm{OOCH}_{3}\right), 3.36\left(\mathrm{~s}, 3 \mathrm{H}, \mathrm{OCH}_{3}\right), 2.40\left(\mathrm{~s}, 3 \mathrm{H}, \mathrm{CH}_{3}\right), 2.7-2.2$ $\left(\mathrm{m}, 3 \mathrm{H}, \mathrm{CH}_{2}\right.$ and $\left.\mathrm{CHH}\right), 2.15-1.95(\mathrm{~m}, 1 \mathrm{H}, \mathrm{CH} H) ;{ }^{13} \mathrm{C} \mathrm{NMR} \delta$ $141.9(\mathrm{~s}, \mathrm{C}-9 \mathrm{a}), 139.0$ and $133.2(\mathrm{~s}, \mathrm{Ar} \mathrm{C}), 129.8,129.6$, and 129.0 (d, Ar C), 118.1 (s, C-5a), 117.3 (d, Ar C), 114.8 and 113.0 (s, CN), 112.4 (d, $\mathrm{Ar} \mathrm{C}$ ), 73.3 (t, $\mathrm{CH}_{2} \mathrm{OCH}_{3}$ ), 63.94 [d, $\mathrm{NCH}$ (bridgehead)], $60.4\left[\mathrm{~d}, \mathrm{NCH}\left(\mathrm{CH}_{2} \mathrm{OCH}_{3}\right)\right], 59.3\left(\mathrm{q}, \mathrm{CH}_{2} \mathrm{OCH}_{3}\right), 53.1$ [d, ArCH$\left(\mathrm{C}_{6} \mathrm{H}_{4} \mathrm{CH}_{3}\right)$ ], 43.1 [s, $\mathrm{C}(\mathrm{CN})_{2}$ ], 28.7 and $26.1\left(\mathrm{t}, \mathrm{CH}_{2}\right), 21.2(\mathrm{q}$ $\left.\mathrm{C}_{6} \mathrm{H}_{4} \mathrm{CH}_{3}\right) ; \mathrm{IR}(\mathrm{KBr}) 2255(\mathrm{CN}) \mathrm{cm}^{-1}$; mass spectrum, $m / e 357.178$ $\left(\mathrm{M}^{+}\right.$, calcd 357.184). Anal. Calcd for $\mathrm{C}_{23} \mathrm{H}_{23} \mathrm{~N}_{3} \mathrm{O}\left(M_{\mathrm{r}} 357.456\right)$ : C, $77.28 ; \mathrm{H}, 6.49 ; \mathrm{N}, 11.75$. Found: C, 77.08; H, 6.46; N, 11.69.

$(1 \alpha, 3 \mathrm{a} \beta, 5 \alpha)-( \pm)$ - and $(1 \alpha, 3 \mathrm{a} \beta, 5 \beta)-( \pm)-1,2,3,3 \mathrm{a}$-tetrahydro1-(methoxymethyl)-5-(4-methylphenyl) pyrrolo[1,2-a ]quinoline-4,4(5H)-dicarbonitrile $(\mathbf{7 q}$ and $10 q)$ : ratio $97: 3$. Major isomer (7q): $\mathrm{mp} 170-173^{\circ} \mathrm{C}(\mathrm{MeOH}) ;{ }^{1} \mathrm{H}$ NMR $(200 \mathrm{MHz})$ $\delta$ 7.4-7.1 (m, $5 \mathrm{H}, \mathrm{Ar} \mathrm{H}), 6.8-6.6(\mathrm{~m}, 3 \mathrm{H}, \mathrm{Ar} \mathrm{H}), 4.58$ [s, I H, $\left.\operatorname{ArCH}\left(\mathrm{C}_{6} \mathrm{H}_{4} \mathrm{CH}_{3}\right)\right], 4.1-3.9\left[\mathrm{~m}, 2 \mathrm{H}, \mathrm{NCH}\left(\mathrm{CH}_{2} \mathrm{OCH}_{3}\right)\right.$ and $\mathrm{NCH}$ (bridgehead)], 3.66 (dd, $1 \mathrm{H}, J=9.3$ and $2.6 \mathrm{~Hz}, \mathrm{CH} \mathrm{HOCH}_{3}$ ), 3.23 (dd, $1 \mathrm{H}, J=9.3$ and $\left.9.3 \mathrm{~Hz}, \mathrm{CH} H O C H_{3}\right), 3.39\left(\mathrm{~s}, 3 \mathrm{H}, \mathrm{OCH}_{3}\right.$ ), 
2.5-2.0 (m, $\left.4 \mathrm{H}, \mathrm{CH}_{2}\right), 2.31\left(\mathrm{~s}, 3 \mathrm{H}, \mathrm{CH}_{3}\right) ;{ }^{13} \mathrm{C} \mathrm{NMR} \delta 141.8(\mathrm{~s}$, C-9a), 139.0 and 133.4 (s, Ar C), 130.3, 129.5, and 129.0 (d, Ar C), 119.3 (s, C-5a), 117.7 (d, Ar C), 114.3 and 112.5 (s, CN), 112.0 (d, $\mathrm{Ar} \mathrm{C}$ ), 72.1 (t, $\mathrm{CH}_{2} \mathrm{OCH}_{3}$ ), 64.0 [d, $\mathrm{NCH}$ (bridgehead)], 59.1 (q, $\left.\mathrm{OCH}_{3}\right), 57.1$ and $53.2\left[\mathrm{~d}, \mathrm{NCH}\left(\mathrm{CH}_{2} \mathrm{OCH}_{3}\right)\right.$ and $\mathrm{ArCH}\left(\mathrm{C}_{6} \mathrm{H}_{4} \mathrm{CH}_{3}\right)$ ], $44.6\left[\mathrm{~s}, \mathrm{C}(\mathrm{CN})_{2}\right], 28.0$ and $26.9\left(\mathrm{t}, \mathrm{CH}_{2}\right), 21.2\left(\mathrm{q}, \mathrm{CH}_{3}\right)$; IR $(\mathrm{KBr})$ 2260 (CN) $\mathrm{cm}^{-1}$; mass spectrum, $m / e 357.189$ ( ${ }^{+}$, calcd 357.184 ). Anal. Calcd for $\mathrm{C}_{23} \mathrm{H}_{23} \mathrm{~N}_{3} \mathrm{O}\left(M_{\mathrm{r}} 357.456\right)$ : C, 77.28; $\mathrm{H}, 6.49 ; \mathrm{N}$, 11.75. Found: C, $76.91 ; \mathrm{H}, 6.58 ; \mathrm{N}, 11.71$.

X-ray Structure Determination of $6 \mathrm{n}$. The crystal structure of $6 \mathrm{n}$ was determined by X-ray diffraction. Crystal data $\mathrm{C}_{18} \mathrm{H}_{21} \mathrm{~N}_{3} \mathrm{O}$ : triclinic, space group $P \overline{1} ; a=15.031$ (1) $\AA, b=8.190$ (2) $\AA, c=6.938(1) \AA, \alpha=79.86(1)^{\circ}, \beta=78.55(1)^{\circ}, \gamma=94.82$ (1) ${ }^{\circ} V=817.7$ (3) $\AA^{3} ; Z=2, d_{\text {calcd }}=1.20 \mathrm{~g} \mathrm{~cm}^{-3} ; \mu=0.7 \mathrm{~cm}^{-1}$. Reflections were measured in the $\omega / 2 \theta$ scan mode, using graphite monochromated Mo $\mathrm{K} \alpha$ radiation [scan width $(\omega) 1.40+0.6$ tan $\theta]$. The structure was solved by direct methods and refined with full-matrix least-squares methods. A total of 1583 reflections with $F_{0}{ }^{2}>3 \sigma\left(F_{0}^{2}\right)$ was used in the refinement. The number of parameters refined was 284 [scale factor, extinction parameter, positional parameters of all atoms, and thermal parameters (isotropic for $\mathrm{H}$ atoms, anisotropic for others)]. The final $R$ factors were $R=3.6 \%, R_{\mathrm{w}}=4.6 \%$. All calculations were done with SDP. ${ }^{24}$

Acknowledgment. This investigation was supported by the Netherlands Foundation of Chemical Research

(24) Structure Determination Package; Frenz, B. A. and Associates Inc., College Station, TX, and Enraf-Nonius, Delft, 1983.
(SON) with financial aid from the Netherlands Organization for Scientific Research (NWO).

Registry No. 1a, 446-52-6; 1b, 445-27-2; 1c, 68295-43- ?; 2a, 123-75-1; 2b, 765-38-8; 2c, 76946-27-5; 2d, 110-89-4; 2e, 109-05-7; 2f, 1484-80-6; 2g, 117607-54-2; 3a, 58028-74-3; 3b, 117677-92-6; 3c, 117677-93-7; 3d, 34595-26-1; 3e, 117607-55-3; 3f, 117607-56-4; 3g, 117607-57-5; 3h, 70243-84-4; 3i, 117677-94-8; 3j, 117677-95-9; 3k, 39911-06-3; 31, 117607-58-6; 3m, 117607-59-7; 3n, 117607-60-0; 3o, 117607-61-1; 3p, 117607-62-2; 3q, 117607-63-3; 4a, 87698-95-1; 4b, 107743-55-5; 4c, 107743-57-7; 4d, 87698-96-2; 4e, 117607-64-4; 4f, 117607-65-5; 4g, 117607-66-6; 4h, 117607-67-7; 4i, 117607-68-8; 4j, 107797-45-5; 4k, 117607-69-9; 41, 117607-70-2; 4m, 117607-71-3; 4n, 117607-72-4; 5a, 117607-73-5; 5b, 107743-56-6; 5c, 107743-58-8; 5d, 117607-74-6; 5e, 117607-75-7; 5f, 117607-76-8; 5g, 117607-77-9; 5h, 117607-78-0; 5i, 117677-96-0; 5j, 107797-46-6; 5k, 117607-79-1; 5l, 117607-80-4; 5m, 117607-81-5; 5n, 117607-82-6; 5o, 117607-83-7; 5p, 117607-84-8; 5q, 117607-85-9; 6c, 107743-59-9; 6g, 117607-86-0; 6j, 107797-47-7; 6n, 117607-87-1; 6p, 117607-88-2; 6q, 117607-89-3; 7c, 107743-64-6; 7g, 117607-90-6; 7j, 107797-48-8; 7n, 117677-97-1; 7p, 117677-98-2; 7q, 117677-99-3; 8o, 117607-91-7; 8p, 117607-92-8; 8q, 117607-93-9; 9q, 117678-00-9; 10q, 117678-01-0; 2,4'$\mathrm{H}_{3} \mathrm{CC}_{6} \mathrm{H}_{4} \mathrm{CH}(\mathrm{OH}) \mathrm{C}_{6} \mathrm{H}_{4} \mathrm{~F}$, 117607-94-0; (4-methylphenyl)magnesium bromide, 4294-57-9; malononitrile, 109-77-3.

Supplementary Material Available: Tables of positional and thermal parameters, bond distances and bond angles for $6 \mathrm{n}$ ( 6 pages). Ordering information is given on any current masthead page.

\title{
Stereochemical Aspects of the "tert-Amino Effect". 2. Enantio- and Diastereoselectivity in the Synthesis of Quinolines, Pyrrolo[1,2-a ]quinolines, and [1,4]Oxazino[4,3-a ]quinolines
}

\author{
Walter H. N. Nijhuis, ${ }^{\dagger}$ Willem Verboom, ${ }^{\dagger}$ A. Abu El-Fadl, ${ }^{\ddagger}, 8$ Gerrit J. van Hummel, ${ }^{\dagger}$ and \\ David N. Reinhoudt*,† \\ Laboratories of Organic Chemistry and Chemical Physics, University of Twente, 7500 AE Enschede, \\ The Netherlands
}

Received June 20, 1988

\begin{abstract}
Thermal isomerization of the optically pure 2-vinyl- $N, N$-dialkylanilines, with a methyl or an ethyl substituent $\left(\mathrm{R}^{2}\right)$ at the $\alpha$-position of the $N, N$-dialkyl moiety, $4 \mathrm{a}\left(\mathrm{R}^{1}=\mathrm{H}\right), 4 \mathrm{~b}\left(\mathrm{R}^{1}=\mathrm{CH}_{3}\right), 5 \mathrm{a}\left(\mathrm{R}^{1}=\mathrm{H}\right)$, and $6 \mathrm{a}\left(\mathrm{R}^{1}=\mathrm{H}\right)$, affords enantioselectively the optically pure pyrrolo[1,2-a]quinolines $7 \mathbf{a}$ and $7 \mathbf{b}$ and the $[1,4]$ oxazino[4,3-a]quinoline 11 , with the methyl or ethyl substituent $\left(R^{2}\right)$ at the bridgehead carbon atom, and the quinoline 13 , respectively. The optical purity of these quinoline derivatives was determined by ${ }^{1} \mathrm{H}$ NMR spectroscopy in the presence of chiral shift reagents. Heating of the optically pure analogues in which $\mathrm{R}^{2}$ is a methoxymethyl group (4c and 4d) in refluxing 1-butanol yields, besides the compounds $7 \mathrm{c}, \mathbf{d}$ with the methoxymethyl group at the bridgehead carbon atom, also the regioisomers $8 c, d$ and $9 c, d$ that are enantiomerically pure. Mixtures of the diastereomers $12 a, b$ and $14 a, b$ were obtained by cyclization of compound $\mathbf{5 b}$, with a 3-ethylmorpholinyl group, and of the acyclic amine $6 \mathrm{~b}$, respectively, in refluxing 1-butanol. The compounds $12 \mathrm{a}$ and $14 \mathrm{a}, \mathrm{b}$ were proven enantiomerically pure. The configuration of the compounds $8,9,12$, and 14 was determined by $X$-ray analysis $[( \pm)-12 a]$ and ${ }^{1} \mathrm{H}$ NMR and ${ }^{1} \mathrm{H}$ NOE difference spectroscopy. These results provide conclusive evidence for the mechanism of these cyclization reactions, which are further examples of the "tert-amino effect". The effect of substituents on the enantio- and diastereoselectivity of the cyclization is discussed.
\end{abstract}

\section{Introduction}

In a previous paper on the $\mathrm{C}-\mathrm{C}$ bond formation via the "tert-amino effect", we have described the influence of steric and electronic effects of substituents on the regioselectivity of the cyclization of 2-vinyl- $N, N$-dialkyl-

\footnotetext{
${ }^{\dagger}$ Laboratory of Organic Chemistry.

${ }^{\ddagger}$ Laboratory of Chemical Physics.

Present address: Physics Department, Faculty of Science, Assiut University, Assiut, Egypt.
}

anilines, yielding pyrrolo[1,2-a]quinolines and benzo[c]quinolizines. ${ }^{1}$

As a further extension we have investigated the possible synthesis of optically pure quinoline derivatives by thermal conversion of optically pure 2 -vinyl- $N, N$-dialkylanilines. Moreover, cyclization of chiral 2-vinyl- $N, N$-dialkylanilines could provide conclusive evidence for the proposed

(1) Nijhuis, W. H. N.; Verboom, W.; Abu El-Fadl, A.; Harkema, S. Reinhoudt, D. N. J. Org. Chem., preceding paper in this issue. 